\title{
Onset of the Ordovician cephalopod radiation - evidence from the Rochdale Formation (middle Early Ordovician, Stairsian) in eastern New York
}

\author{
BJÖRN KRÖGER* \& ED LANDING $\dagger$
}

*Université Lille 1, Laboratoire Géosystèmes (UMR 8157 CNRS), UFR des Sciences de la Terre - bâtiment SN5, 59655 Villeneuve d'Ascq cedex, France; formerly Museum für Naturkunde, Humboldt Universität zu Berlin, Invalidenstrasse 43, D-10115 Berlin, Germany

$\dagger$ New York State Museum, Albany, New York 12230, USA

(Received 19 February 2007; accepted 19 September 2007; First published online 9 May 2008)

\begin{abstract}
The Rochdale Formation of eastern New York (= Fort Ann and lower Bascom formations, designations abandoned) is now recognized to record the earliest stages of the Great Ordovician Radiation of cephalopods. The earliest Bassleroceratidae, Tarphyceratidae and endoceridans on the east Laurentian shallow carbonate platform occur in the upper, thrombolite-bearing member of the Rochdale. This fauna demonstrates that the earliest radiation of Ordovician nautiloids took place in the late Tremadocian and is best recorded in tropical platform facies. Revision of this cephalopod fauna based on approximately 190 specimens collected along a $200 \mathrm{~km}, \mathrm{~N}-\mathrm{S}$ belt in easternmost New York has provided new information on inter- and intraspecific variation of earlier described species. The ellesmerocerid Vassaroceras and the endocerids Mcqueenoceras and Paraendoceras are emended. New taxa include Bassleroceras champlainense sp. nov. and B. triangulum sp. nov., Mccluskiceras comstockense gen. et sp. nov., Exoclitendoceras rochdalense gen. et sp. nov. and Paraendoceras depressum sp. nov. A rank abundance plot of 146 specimens from a locality in the Lake Champlain lowlands provides information on the community structure of a nautiloid fauna in which the longiconic cyrtoconic Bassleroceras is shown to dominate strongly. The nautiloid community structure of the Rochdale Formation is similar to that of the underlying Tribes Hill Formation (late early Tremadocian) with respect to the depositional setting, diversity and evenness but displays a remarkably increased taxonomic distinctness.
\end{abstract}

Keywords: Early Ordovician, cephalopods, evolution, Laurentia, New York.

\section{Introduction}

The Beekmantown Group (Clarke \& Schuchert, 1899) is a succession of carbonate-dominated, tropical platform units on the northeastern margin of the Laurentian platform in eastern New York, western Vermont and adjacent Ontario and Quebec that spans the Late Cambrian-Middle Ordovician (see Landing, Westrop \& Van Aller Hernick, 2003; Landing \& Westrop, 2006). The group comprises a succession of unconformity-bounded, relatively thin (about $60 \mathrm{~m}$ or less) depositional sequences (Landing, Westrop \& Knox, 1996; Landing, Westrop \& Van Aller Hernick, 2003) and yields some of the oldest cephalopod faunas in North America. These cephalopods from the upper part of the Late Cambrian Little Falls Formation (Rathbunville Limestone member) and unconformably overlying Early Ordovician Tribes Hill Formation (late Skullrockian Stage and late early Tremadocian Series) have been recently described (Landing et al. 2007; Kröger \& Landing, 2007), with the latter unit yielding a relatively high-diversity ellesmerocerid assemblage.

*Author for correspondence: bjoekroe@gmx.de
This report is a restudy and revision of the cephalopods of the Rochdale Formation (Knopf, 1927), a Stairsian Stage (late Tremadocian) unit that unconformably overlies the Tribes Hill Formation. The fauna of the Rochdale Formation proved to be of particular importance because it contains the earliest known bassleroceratids, tarphyceratids and endoceridans, and thus represents the onset of the Great Ordovician Radiation of cephalopods. This study allowed a direct comparison with the revised cephalopod fauna of the underlying Tribes Hill Formation (Kröger \& Landing, 2007). The quantity of cephalopod material from the Tribes Hill and Rochdale Formation allows comparisons of the faunal composition of these successive stratigraphic units. The new data provide a unique insight into the architecture of faunal change during the beginning of the Great Ordovician Radiation of cephalopods.

\section{Material and methods}

A few Rochdale Formation cephalopods were noted and described by Dwight (1879, 1880, 1881, 1884, 
1889) and Ulrich et al. (1944), but their stratigraphic succession and palaeoenvironmental context have never been documented. Dwight's collections, including his illustrated types (Dwight, 1884), were transferred from Vassar College in Poughkeepsie, New York, to the New York State Museum (NYSM) Paleontology Collection, probably in the first half of the 20th century. Most of the cephalopods discussed herein were collected in the 1940s by R. H. Flower during his tenure at the New York State Museum (NYSM). Flower $(1955,1956,1964 a, 1976)$ repeatedly referred to this material in the NYSM Paleontology Collection but never conducted a thorough description of the fauna. Additional material was collected by E. Landing and B. Kröger during fieldwork in 2006.

The taxonomy of the Rochdale Formation cephalopods was revised on the basis of all available material. The revised taxa were used in a parsimony analysis of early endoceridans. The analysis involved use of PAUP 4.0 (Swofford, 1993). The richness of the samples was calculated with Chao's (1984) technique following Chazdon et al. (1998). The advantage of this method is that it is not based on the parameters of a species abundance model that has previously been fitted to the data (Magurran, 2004). Thus, the Chao richness estimators provide a very robust diversity measure.

The number of species in a sample is estimated as $\mathrm{S}_{\text {Chao } 1}=\mathrm{S}_{\mathrm{obs}}+\left(\mathrm{F}_{1}{ }^{2} / 2 \mathrm{~F}_{2}\right)$, where $\mathrm{S}_{\mathrm{obs}}$ is the number of species in a sample, $F_{1}$ is the number of observed species represented by a single specimen, and $F_{2}$ is the number of species represented. In addition, the Simpson index $(D)$ was calculated to provide an estimate for the heterogeneity of the samples (evenness). For calculation of $\mathrm{S}_{\text {Chaol }}$ and $D$, the software EstimateS (Colwell, 2005) was used.

Taxonomic distinctness $\left(\Delta^{+}\right)$(Clarke \& Warwick, $1998,1999)$ was calculated as a proxy for sample disparity. Taxonomic distinctness provides a measure for the relatedness of the species in a sample, and is calculated as $\Delta^{+}=\left(\Sigma \Sigma_{\mathrm{i}<\mathrm{j}} \omega_{\mathrm{ij}}\right) /\left(\mathrm{s}\left(\mathrm{s}^{-1}\right) / 2\right)$, where $s$ is the number of species in a sample and $\omega$ is the taxonomic path length between species $i$ and $j$. The path length assigned to each level of the taxonomic hierarchy is weighted as one in the calculation.

\section{Geological setting}

The Beekmantown Group forms an extensive outcrop belt in eastern New York and western Vermont. This outcrop belt rings the middle Proterozoic Adirondack Mountain dome in northern New York, is present in the autochthonous and parautochthonous successions of western Vermont on the east side of Lake Champlain, and crops out under the leading (western) edge of the Taconic allochthon from Washington County to Dutchess County on the east side of the Hudson River valley (Figs 1,2).

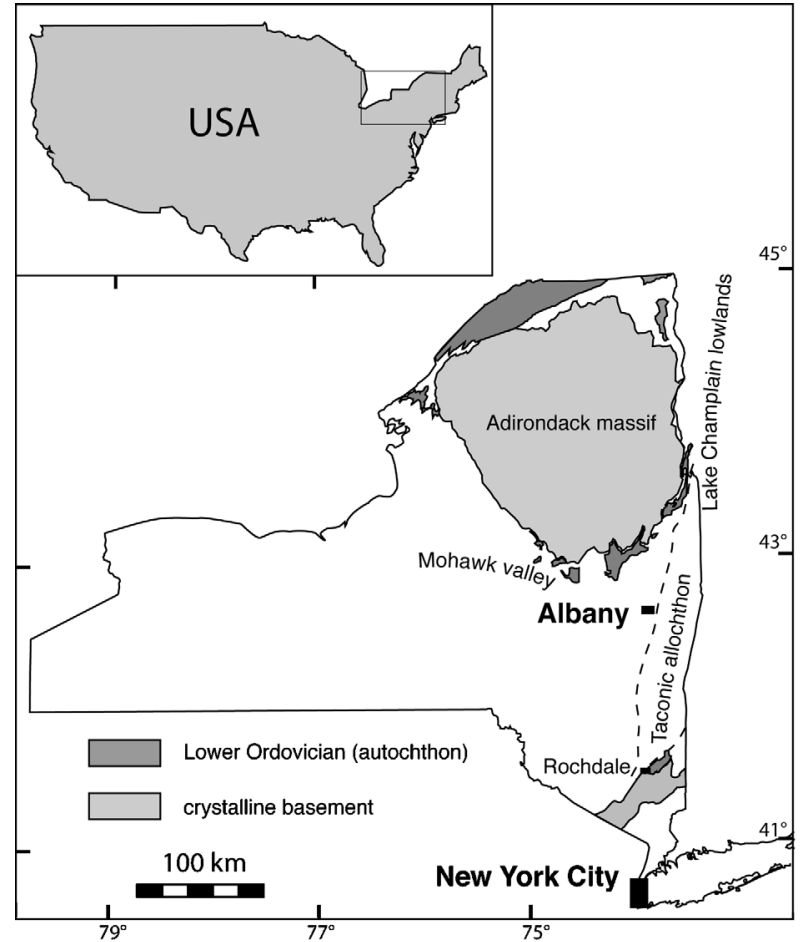

Figure 1. Map of the outcrop area of the autochthonous Lower Ordovician strata in New York west of the leading edge of the Taconic allochthon.

\begin{tabular}{|c|c|c|c|c|}
\hline \multirow{6}{*}{$\begin{array}{l}\frac{c}{\frac{\pi}{0}} \\
\frac{\mathrm{U}}{2} \\
\frac{0}{0} \\
\frac{0}{0}\end{array}$} & 峁 & $\begin{array}{l}\text { conodonts } \\
\text { North } \\
\text { Atlantic }\end{array}$ & $\begin{array}{l}\text { New York } \\
\text { formations }\end{array}$ & $\begin{array}{l}\text { conodonts } \\
\text { North } \\
\text { America }\end{array}$ \\
\hline & & O.evae & & Reuterodontus andinus \\
\hline & \multirow[t]{2}{*}{$\bar{\amalg}$} & Pr.elegans & \multirow{2}{*}{$\begin{array}{l}\text { Fort Cassin } \\
\text { Formation }\end{array}$} & \multirow{2}{*}{ Oepikodus communis } \\
\hline & & $\begin{array}{l}\text { Oel. elongatus } \\
\text { Acodus deltatus }\end{array}$ & & \\
\hline & \multirow{6}{*}{ 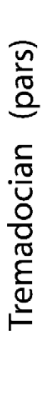 } & Par.gracilis & & \multirow{2}{*}{$\begin{array}{l}\text { Acodus deltatus - } \\
\text { Oneotus costatus }\end{array}$} \\
\hline & & \begin{tabular}{|c|} 
Tripodus \\
D. aff.amoenus
\end{tabular} & & \\
\hline \multirow{4}{*}{3} & & \multirow{3}{*}{ Pal. deltifer } & \multirow{2}{*}{$\begin{array}{l}\text { Rochdale } \\
\text { Formation }\end{array}$} & Macerodus dianae \\
\hline & & & & Low diversity interval \\
\hline & & & \multirow[b]{2}{*}{$\begin{array}{l}\text { Tribes Hill } \\
\text { Formation }\end{array}$} & Rossodus manitouensis \\
\hline & & $\begin{array}{l}\text { Cordylodus } \\
\text { angulatus }\end{array}$ & & upper Fauna B \\
\hline
\end{tabular}

Figure 2. Stratigraphy of the autochthonous Lower Ordovician strata of New York.

The Rochdale Formation is one of the least areally extensive formations of the Beekmantown Group in this region. Landing \& Westrop (2006; also Landing, 2002; Landing, Westrop \& Van Aller Hernick, 2003; Landing, Westrop \& Keppie, 2007) determined that the Tribes Hill Formation, the lowest Ordovician unit of the Beekmantown Group, was deposited during a eustatic high that submerged Laurentia as far as Wisconsin and Minnesota in late early Tremadocian times. However, 
the next overlying Beekmantown Group formation is a depositional sequence that records a late Tremadocian eustatic high that did not lead to transgression west of the roughly $\mathrm{N}-\mathrm{S}$ line defined by the modern Hudson River-Lake Champlain lowlands (Fig. 1).

In recent reports (Landing, Westrop \& Van Aller Hernick, 2003; Landing \& Westrop, 2006), existing problems in stratigraphic nomenclature have meant that this late Tremadocian carbonate-dominated lithosome in Washington County, eastern New York, has been referred to as the so-called 'Fort Ann Formation'. As a result of fieldwork, supporting this report and on associated conodont and trilobite faunas, the stratigraphy and lithofacies of the 'Fort Ann Formation' have been described. What became obvious during this work along the $\sim 200 \mathrm{~km}$ distance from southern Dutchess County to northern Washington County, eastern New York, was that the Rochdale Formation (Knopf, 1927) in Dutchess County is fully comparable to the Fort Ann Formation (Flower, 1968) to the north in Washington County (see Fisher, 1984). Information to be documented fully in a subsequent report shows that both units are carbonate-dominated (largely dolomitized by hydrothermal activity), unconformably overlie the Tribes Hill Formation with local evidence of subaerial erosion, and unconformably underlie quartz arenite-dominated strata (Sciota Member) that form the lower part of the late Early Ordovician (Floian, middle Arenigian) Fort Cassin Formation. In addition, both the Rochdale Formation and 'Fort Ann Formation' consist of a lower member characterized by restricted-marine carbonates and of an upper member with thrombolites and abundant cephalopods that define two successive assemblages (Fig. 3). As concluded by Landing \& Westrop (2006, p. 967), the Rochdale Formation is the senior synonym of the 'Fort Ann Formation', a unit for which a type section was never specified and which was named for a village that is actually located on Late Ordovician synorogenic flysch. Further north in western Vermont, the Bascom Formation (Cady, 1945) includes three divisions that indicate lateral equivalency and junior synonymy with the upper Tribes Hill, Rochdale and Fort Cassin formations (Landing, Westrop \& Van Aller Hernick, 2003).

\section{Rochdale Formation cephalopod localities}

The exact stratigraphic horizons of the specimens collected by D. W. Dwight and R. H. Flower from the Rochdale Formation generally cannot be determined with accuracy because their collection sites are now heavily vegetated or could not be precisely located based on the published information or on the locality descriptions reposited with specimens in the NYSM Paleontology Collection. Dwight's notebooks that document his $1870 \mathrm{~s}-1880$ s work on Dutchess County palaeontology and geology are stored in the NYSM Paleontology Collection, but sadly, his handwriting

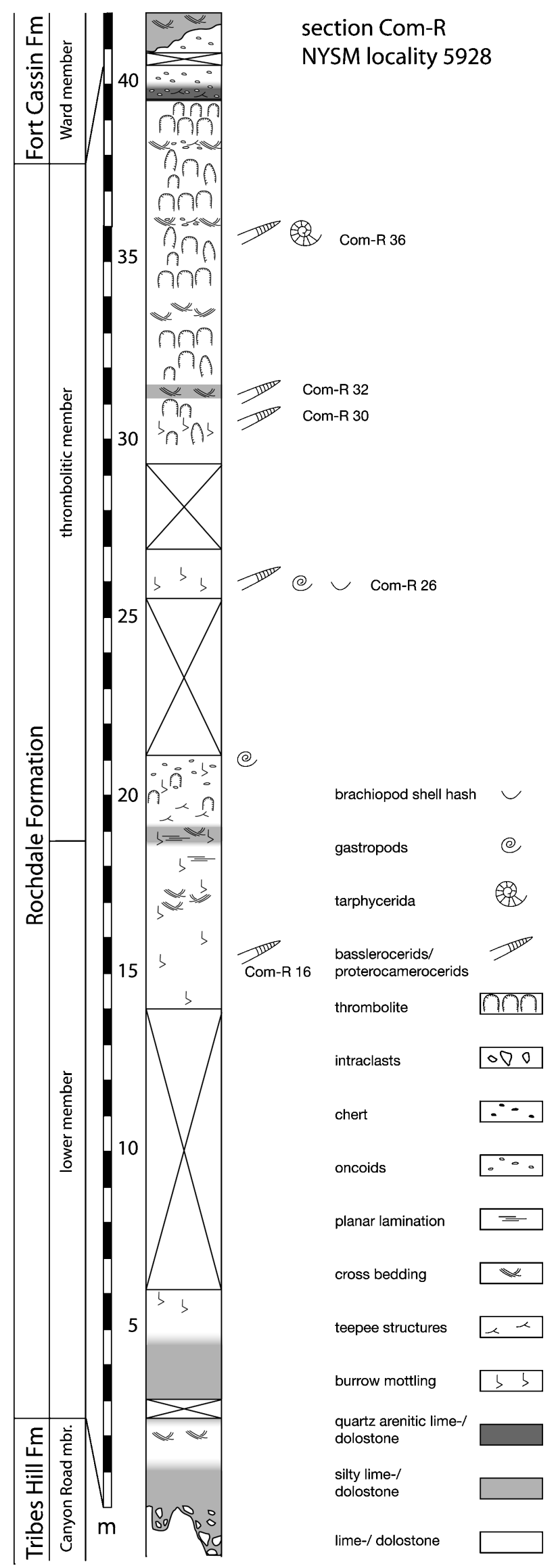

Figure 3. Rochdale Formation (Stairsian) at the Comstock section (Com-R), Washington County, New York. 
is illegible. In the following sections, cephalopod localities are described from north to south along the outcrop belt of the Rochdale Formation.

\section{4.a. Steves Farm area and NYSM locality $\mathbf{5 9 3 3}$}

The northernmost site in Washington County, New York, from which R. H. Flower collected Rochdale Formation cephalopods is spartanly described under NYSM Paleontology Collection locality 5933 as 'hillside north of dirt road leading in to Steves farm, 31/4 miles NE of Comstock, N.Y. ... 12 specimens.' This locality lies on the SE slope of the $108 \mathrm{~m}$ (360 foot) hill on which Landing, Westrop \& Van Aller Hernick (2003, fig. 3) described a SE-dipping, uppermost Cambrianlowest Ordovician section (upper Little Falls-lowest Tribes Hill formations). The hill is now densely wooded, and our traverse of the Tribes Hill-RochdaleFort Cassin formations north of Rathbunville Road did not lead to the relocation of NYSM locality 5933.

\section{4.b. Comstock section and NYSM locality $\mathbf{5 9 2 8}$}

The most completely exposed section in the Rochdale Formation in Washington County, New York, lies east of Comstock village and on the north side of Rte 22 (Fig. 3). This gently E-dipping $\left(5-12^{\circ}\right)$ section (our section Com-R; Fig. 3) is a continuation of the 'Comstock section' described through the underlying Little Falls and Tribes Hill formations by Landing, Westrop \& Van Aller Hernick (2003, pp. 79, 80, fig. 4). The Rochdale unconformably overlies the Tribes Hill, and there is up to $2.1 \mathrm{~m}$ of erosional relief on the Tribes Hill in a natural exposure located about $50 \mathrm{~m}$ north of Rte 22. The Rochdale is $41.25 \mathrm{~m}$ thick, with an upper contact with dark grey quartz arenite of the basal Fort Cassin Formation exposed at the end of the road-cut on Rte 22.

R. H. Flower collected cephalopods from the Rochdale Formation at the Comstock section. This cephalopod fauna is stored in the NYSM Paleontology Collection as 'NYSM locality 5928'. A hand-drawn map left with this collection by R. H. Flower indicates that he recovered abundant specimens of Lecanospira from strata exposed on the northeast corner of an electrical transformer station on the north side of Rte 22 (about 16-21 m above base of Rochdale). However, he did not detail the horizon(s) of NYSM locality 5928.

The entire Rochdale section represents a deepeningshoaling, macroscale sequence with several subordinate cycles. In the lower $6.4 \mathrm{~m}$, silty, locally microcross-bedded dolostone without shelly macrofaunas dominates, and yields sparse conodonts referable to the Low Diversity Interval or lower Macerodus dianae Zone (Landing, Westrop \& Van Aller Hernick, 2003). Above a covered interval $(6.4-13.7 \mathrm{~m})$, fossiliferous dolostones and dolomitic limestones appear immediately north of the transformer station, and the lowest thrombolites occur in an intraclast matrix at $18 \mathrm{~m}$. Cephalopods are very rare, and are only known from a few poorly preserved bassleroceratid fragments from beds at $15 \mathrm{~m}$ and $16 \mathrm{~m}$ above the base of the succession.

A change in cephalopod faunas occurs $26 \mathrm{~m}$ above the base of the Comstock section, with the appearance of common bassleroceratids and straight endoceridans, and their reappearance at higher horizons (29.3, $30.4,31.5,35.4,36.2,38.2,39.1 \mathrm{~m})$. Tarphycerids appear in a thrombolite bed at $36.2 \mathrm{~m}$. This part of the section consists of several sequences formed of biostromal thrombolites in intraclast pack- to grainstone matrix, which are topped by laminated or cross-bedded intraclast-pebble-rich limestones with teepee structures. The top of the Rochdale Formation is a laminated, quartzose dolostone with chert-filled vugs after evaporites.

The cephalopods at Comstock and in NYSM locality 5928 are more abundant in the upper Rochdale Formation. These thrombolitic- and intraclastdominated horizons are very similar to the cephalopodbearing beds of the underlying upper Tribes Hill Formation (Kröger \& Landing, 2007) and represent the shoaling interval of a highstand systems tract. Briefly summarized, the depositional environment and habitat of the Rochdale cephalopods were almost identical with those of the cephalopods from NYSM locality 5898 in the underlying Tribes Hill Formation at Comstock (Kröger \& Landing, 2007). However, as discussed below, the composition of the cephalopod fauna of these two formations differs drastically.

\section{4.c. Starbuck Road (NYSM locality 5916)}

R. H. Flower collected a few cephalopods ( 8 specimens, 2 remaining in NYSM Paleontology Collection) from a spot locality in the Rochdale Formation on the north side of Starbuck Road 'just west of a house near the point where Winchell Creek crosses the road' (description of NYSM Paleontology Collection locality 5916). This locality lies in the upper Rochdale Formation (in upper 'Fort Ann' Formation on Fisher's (1984) map). Flower's pasture section is now heavily wooded with second growth, and the locality was not relocated in this study. It lies $5 \mathrm{~km} \mathrm{SW}$ and along strike from the Comstock section.

\section{4.d. Baldwin Corners Road (NYSM locality 5904)}

R. H. Flower made a larger collection (24 specimens, 5 remaining in NYSM Paleontology Collection locality 5904) just N of Baldwin Corners Road from a pasture outcrop $6.6 \mathrm{~km} \mathrm{SW}$ and along strike from the Comstock section. The locality lay approximately $400 \mathrm{~m} \mathrm{~W}$ of the three-way intersection where the roughly W-E-running Baldwin Corners Road turns into Bull Hill and Hall roads. NYSM 5904 locality was not relocated in this 
study, but is in the upper Rochdale Formation (in upper 'Fort Ann' Formation on Fisher's (1984) map).

\section{4.e. Smith Basin and NYSM locality 5897}

The gently SE-dipping $\left(13^{\circ}\right)$ Smith Basin section (our section SB-R; Fig. 4) lies about $12.3 \mathrm{~km} \mathrm{SSW}$ and along strike from the Comstock section. Although once a classic pasture section that exposed much of the Potsdam Sandstone and Beekmantown Group (Flower, 1964a; Rodgers \& Fisher, 1969), much of this sequence in central Washington County is now overgrown and covered. Landing, Westrop \& Van Aller Hernick (2003) documented a biostratigraphic break at Smith Basin between the Tribes Hill Formation (Rossodus manitouensis Zone) and overlying Rochdale Formation ('Fort Ann Formation') (Low Diversity Interval or Macerodus dianae Zone). An abundant ellesmeroceroid fauna occurs in the massive limestone that comprises the top of the Tribes Hill Formation (Flower, 1964a; Kröger \& Landing, 2007). The Tribes Hill-Rochdale sequence boundary cuts down into this limestone, and shows $1.2 \mathrm{~m}$ of local erosive relief, with boulder-sized clasts (to $120 \times 30 \mathrm{~cm}$ ) of Tribes Hill in the erosive channels.

The Tribes Hill-Rochdale contact is exposed in a low road-cut on the $\mathrm{N}$ shoulder of Rte 149 ( $\mathrm{N} \mathrm{43} 3^{\circ} 21.270^{\prime}$, $\left.\mathrm{W} 73^{\circ} 28.443^{\prime}\right)$. A poorly exposed, $38.3 \mathrm{~m}$ thick section measured along the north side of Rte 149 through the Rochdale includes $11.3 \mathrm{~m}$ of low sucrosic dolostone ledges with a dolomitic lime mudstone (10.4-10.8 m) in the lower Rochdale followed by a long covered interval (11.3-36.0 m). The top of the formation (36.0 $38.8 \mathrm{~m}$ ) features massive thrombolites, with poorly preserved gastropods, cephalopods and trilobites, that are mantled by planar to micro-cross-laminated dolostone.

The bulk of the material collected by R. H. Flower from the Rochdale Formation in the 1940s came from the Smith Basin section, and is reposited under NYSM Paleontology Collection locality number 5897 (146 specimens). An examination of the currently exposed parts of the Smith Basin succession indicates that Flower's cephalopods did not come from the lower part of the sequence, and the lithology is more suggestive of the top.

\section{4.f. Strever Farm Road}

The longest section $(88.5 \mathrm{~m})$ in the Rochdale Formation is exposed 1.7-2.0 km south of Pine Plains village in northern Dutchess County. This SE-dipping (about $10^{\circ}$ ) section on the south slope of an unnamed hill ('Bethel Hill' of Knopf, 1962) was measured from a $40 \mathrm{~cm}$ thick, siliceous, grey quartz arenite that rests on restricted marine dolostones of the Tribes Hill Formation (= 'Halcyon Lake Formation' of Knopf, 1962, abandoned by Landing \& Westrop, 2006). This quartz arenite is the base of the Rochdale Formation

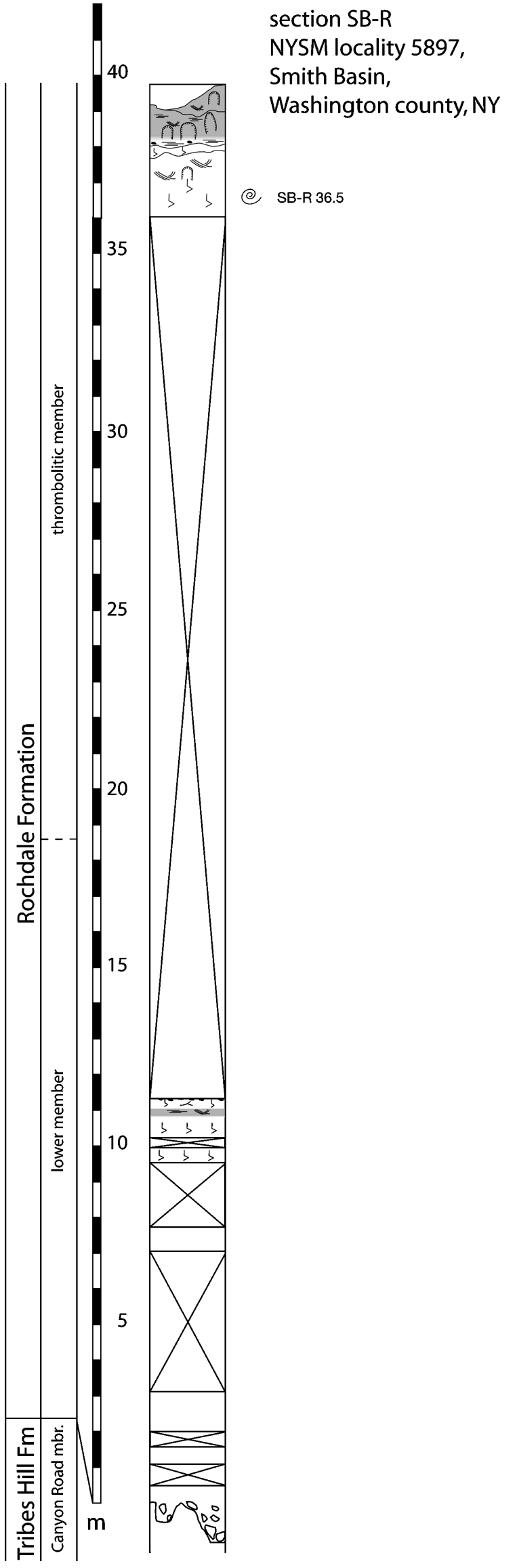

Figure 4. Rochdale Formation (Stairsian) at the Smith Basin section (SB-R), Washington County, New York. 
(Knopf, 1962). A rubbly outcrop of the quartz arenite lies on the east side of Strever Farm Road $170 \mathrm{~m}$ south of the intersection of Strever Farm Road and Rte 82. The Rochdale Formation is exposed to the $\mathrm{SE}$ in intermittent exposures in a horse pasture. These exposures (our section SFR-R; Fig. 5) extend in a belt parallel to Strever Farm Road and end $50 \mathrm{~m} \mathrm{~N}$ of Bethel Crossing road.

The lower $69.5 \mathrm{~m}$ of the Rochdale Formation consists of slaty, light grey, generally burrow-mottled dolostone interbedded with medium-grey lime mudstone and fossil (dominantly gastropod)-intraclast wacketo packstone. Cephalopods reported by R. H. Flower (in Knopf, 1962) have their only known occurrence in the Strever Farm section in an overgrown small quarry in dolomitic limestone (marked on Knopf's (1962) map with an ' $F$ '). Their occurrence is in the lowest thrombolite bed $(69.5-70.0 \mathrm{~m})$ in the section. We observed poorly preserved, moldic specimens of Bassleroceras and endoceroids at this horizon. The upper part of the Rochdale Formation (70-88.3 m) is dominated by dolomitized, massive thrombolitic beds.

The highest exposures of the Rochdale in the Strever Farm Road section probably lie near the top of the formation. An undescribed trilobite collection in the NYSM Paleontology Collection made by W. D. Dwight came from a locality described as $2 \mathrm{~km} \mathrm{~S}$ of Pine Plains. These sparse locality data suggest a site near the top of the Strever Farm Road section. The collection includes Isoteloides peri in an echinoderm grainstone. Both this species and the lithology of the collection are characteristic of the Fort Cassin Formation (= 'Copake Formation' of Knopf, 1927, abandoned by Landing \& Westrop, 2006), the unit that unconformably overlies the Rochdale Formation in eastern New York and Vermont.

\section{4.g. Rochdale}

The village of Rochdale, New York, lies about $3 \mathrm{~km}$ NW of the city of Poughkeepsie. The Early-Middle Ordovician succession in Rochdale is incomplete, and the Late Ordovician (Katian, late Caradocian) Trenton Group unconformably overlies the Rochdale Formation. This unconformity is explained as a result of uplift, erosion and subsequent subsidence as the peripheral bulge passed through the region at the onset of the Taconic orogeny (e.g. Landing, 1988).

Limited outcrop in Rochdale means that only the upper Rochdale Formation is exposed in two NNEtrending ridges. The western ridge has a discontinuous, steeply dipping ( $\left.75^{\circ} \mathrm{SE}\right)$ Rochdale section exposed in low cuts on the north side of Rochdale Road in the middle of the village. The section (our section Ro-R, Fig. 6) is opposite numbers 180 and 182 Rochdale Road, and includes interbedded gastropod-echinoderm-trilobite wacke- and packstone and sucrosic dolostone $(16.2 \mathrm{~m})$ with a thrombolite cap

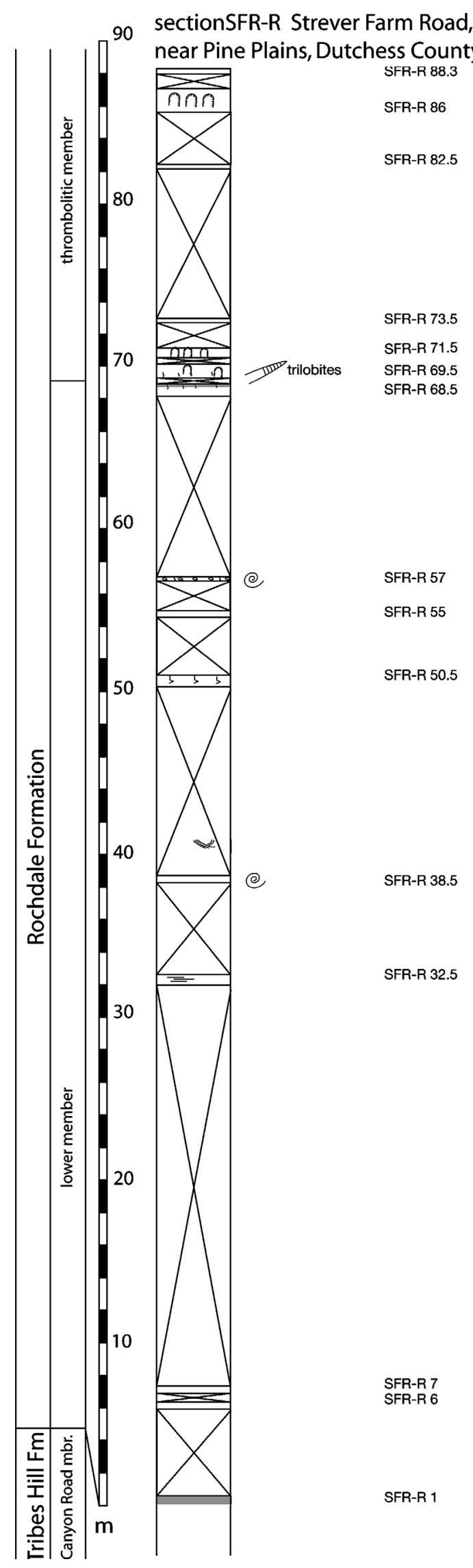

Figure 5. Rochdale Formation (Stairsian) at the Strever Farm Road section (SFR-R), south of Pine Plains, Dutchess County, New York. 
section Ro-R

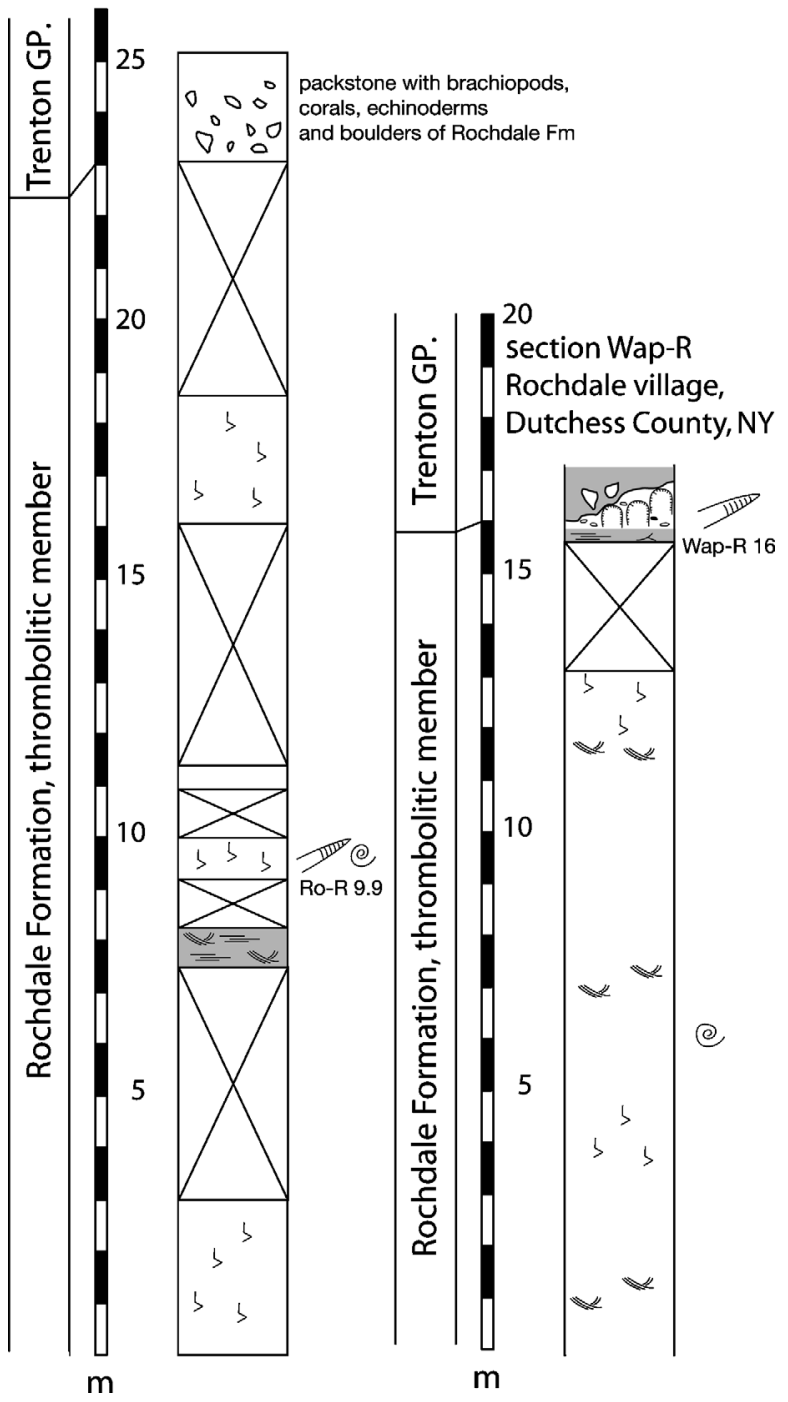

Figure 6. Rochdale Formation (Stairsian) in central Rochdale village (Ro-R) and in eastern Rochdale village near Wappinger Creek (Wap-R), near Poughkeepsie, Dutchess County, New York.

(16.2-17.4 m). Bassleroceras fragments were noted at $9.9 \mathrm{~m}$. A $4.6 \mathrm{~m}$ covered interval separates the top of the exposed Rochdale from a $2 \mathrm{~m}$ thick, carbonate-clast boulder bed at the base of the Trenton Group.

This succession is fault duplicated and replicated in a second ridge just to the east that parallels Wappinger Creek. The basal Trenton Group carbonate boulder bed is exposed in a long cut on the west side of Rochdale Road north of the intersection with Titus Road. A $16.2 \mathrm{~m}$ thick section (our section Wap-R, Fig. 6) in the SSE-dipping $\left(45^{\circ}\right)$ Rochdale Formation was measured at the south end of the Trenton road-cut. The Rochdale succession features interbedded sucrosic dolostone and fossil wackestone beds, with Bassleroceras conchs noted at $6.0 \mathrm{~m}$. The top of the Rochdale (15.7-16.6) is a massive thrombolitic limestone with abundant basslerocerids and endocerids.
Dwight's (1884, p. 251) two cephalopod localities ('D' and ' $F$ ') in Rochdale village are cryptically described and difficult to relate to modern cultural features. Locality ' $\mathrm{D}$ ', a 'richly fossiliferous ledge exposed for 200 to 300 feet each side of the cross-wall between the farms of H. Titus and W. Badgely, about 900 feet northwest of the wooden mill' probably lay on the west side of Titus Road, and along strike with our section Wap-R. Dwight's locality ' $F$ ' 'extending from the northern extremity of ledge D' may be our section Wap-R.

\section{Composition of the cephalopod fauna}

Restudy of the cephalopods from the Tribes Hill Formation (Kröger \& Landing, 2007) and those from the Rochdale Formation emphasizes that exceptionally abrupt changes in composition of cephalopod faunas took place between the Skullrockian (= late early Tremadocian) and Stairsian (=late Tremadocian) stages. In both formations, cephalopods are abundant in comparable lithofacies, and are almost exclusively found in shallow marine, thrombolite-bearing or burrow-churned mudstone facies that occur in the upper part of both formations (e.g. thrombolitic Wolf Hollow and Canyon Road members of the Tribes Hill Formation and informal 'upper thrombolite member' of the Rochdale Formation).

The cephalopod association of the Tribes Hill Formation consists exclusively of Ellesmeroceridae that all bear similarly shaped siphuncles that are marginal in position, while the adult conch length ranges from less than $50 \mathrm{~mm}$ to no more than about $100 \mathrm{~mm}$. The Tribes Hill cephalopods show conch morphologies that range from compressed cyrtoconic breviconic to circular orthoconic longiconic (Kröger \& Landing, 2007).

In contrast, the cephalopods of the Rochdale Formation show a far greater level of high-level taxonomic diversity, and include the Ellesmeroceratidae, Eothinoceratidae, Bassleroceratidae, Proterocameroceratidae, Piloceratidae and Estonioceratidae. Elements of the order Ellesmerocerida persist from the Tribes Hill, and are joined by the Endocerida and Tarphycerida, orders that are prominent later in the Ordovician. A wider range in conch morphologies is present in the Rochdale assemblages, and includes orthoconic, cyrtoconic, gyroconic and tightly coiled forms, while the position and shape of the siphuncle show a wider range of variability. The range of conch sizes is greater in the Rochdale, varying from less than $50 \mathrm{~mm}$ to more than $200 \mathrm{~mm}$ in length.

Of the 18 species recorded from the Rochdale Formation (Fig. 7), 12 (67\%) are exclusively known from outcrops in Washington County. Six species cooccur in the Rochdale area of Dutchess County and of Washington County. Only one species (Eothinoceras americanum Ulrich et al. 1944) is known exclusively 


\begin{tabular}{|c|c|c|}
\hline $\begin{array}{l}\text { Rochdale area (Dutchess county, NY) } \\
\text { Lake Champlain area (Washington county, NY) }\end{array}$ & 7 & \\
\hline Bassleroceras champlainense sp. nov. & $x$ & \\
\hline Bassleroceras smithbasinense sp. nov. & $x$ & \\
\hline Bassleroceras triangulum sp. nov. & $x$ & \\
\hline Bass/eroceras vassarina (Dwight, 1884) & $x$ & $x$ \\
\hline Bassleroceras sp. A & $x$ & \\
\hline Dwightoceras dactyloides (Dwight, 1884) & $x$ & $x$ \\
\hline Ectenolites sp. & $x$ & \\
\hline Vassaroceras henrietta (Dwight, 1884) & $x$ & $x$ \\
\hline Eothinoceras americanum Ulich et al., 1944 & & $x$ \\
\hline Mcqueenoceras aff. jeffersonense Ulrich \& Foerste, 1935 & $x$ & \\
\hline Mccluskiceras comstockense gen. et sp. nov. & $x$ & \\
\hline Clitendoceras saylesi Ulrich and Foerste, 1935 & $x$ & \\
\hline Cotteroceras sp. & $x$ & \\
\hline Exoclitendoceras smithbasinense gen. et sp. nov. & $x$ & \\
\hline Paraendoceras wappingerense (Ulrich et al., 1944) & $x$ & $x$ \\
\hline Paraendoceras depressum sp. nov. & $x$ & $x$ \\
\hline Aphetoceras sp. & $x$ & \\
\hline Campbelloceras sp. & $x$ & $x$ \\
\hline
\end{tabular}

Figure 7. Complete list of nautiloid occurrences in the Rochdale Formation, middle Early Ordovician, New York. The only form limited to the Rochdale area is Eothinoceras americanum Ulrich et al. 1944.

from the Rochdale area. This pattern probably reflects differences in collection effort, and is biased by the number of specimens in the NYSM Paleontology Collection. R. H. Flower collected several hundred specimens in Washington County, while W. B. Dwight's and our collection from Dutchess County comprise only a few dozen specimens. In addition, the amount of outcrop available in Dutchess County is limited in comparison with that of Washington County.

The fact that nearly all species recorded from the Rochdale area are also documented in Washington County demonstrates that both assemblages are likely identical. Mcqueenoceras jeffersonense Ulrich \& Foerste, 1935, is known from the Jefferson City Formation in southern Missouri, but the specimens from the Rochdale Formation differ in some aspects and were only assigned to $M$. aff. jeffersonense.

NYSM locality 5897 east of Smith Basin village in Washington County yielded the largest number of specimens, and probably gives the best representation of the local faunal composition (Table 1). This Rochdale Formation locality overlies NYSM locality 5896 of the underlying Tribes Hill Formation (Kröger \& Landing, 2007). A direct comparison of the cephalopod associations of NYSM localities 5897 and 5896 is
Table 1. Occurrences of nautiloid genera in the Rochdale Formation, middle Early Ordovician in the Smith Basin section, Washington County, New York, (NYSM locality 5897), collected by R. H. Flower during the 1940s

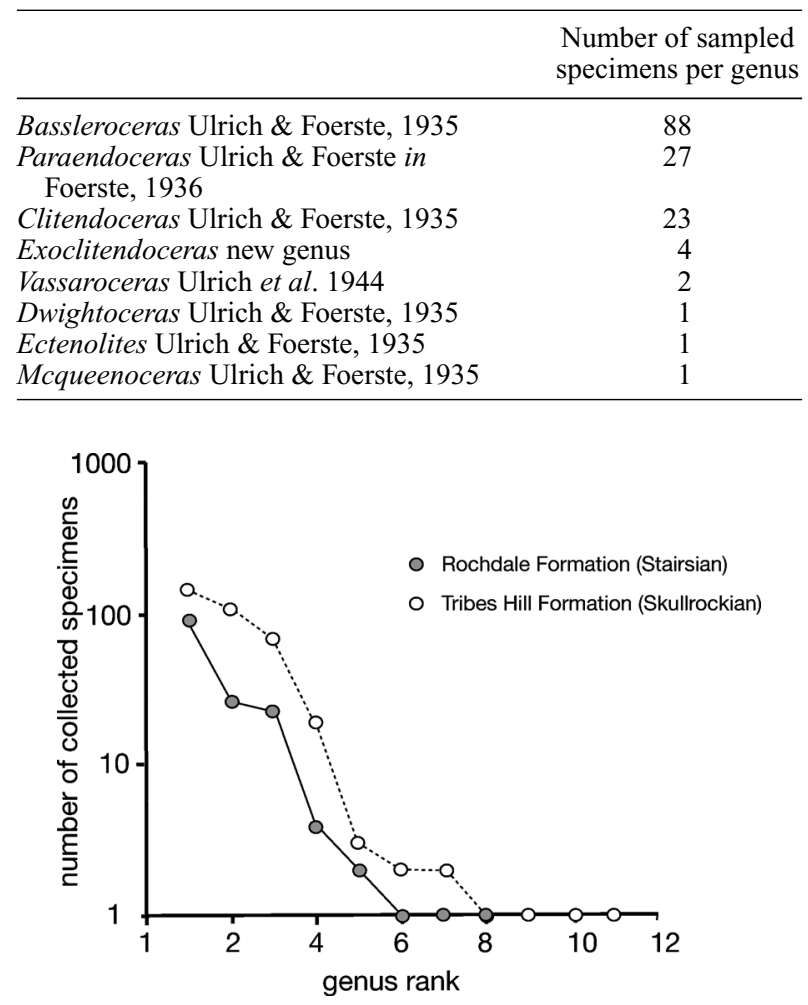

Figure 8. Rank-abundance diagram of the nautiloids of the Tribes Hill (Skullrockian) and Rochdale (Stairsian) formations of the Smith Basin section collected by R. H. Flower during the 1940s. Note the similarity of the two curves. Most common genus of the Tribes Hill Formation is Ectenolites Ulrich \& Foerste, 1935 and of the Rochdale Formation is Bassleroceras Ulrich \& Foerste, 1935.

possible because both associations represent the same geographic position and facies, but a different time interval. The outcrop situation was comparable, and the collections made by R. H. Flower over several years resulted in a comparable number (several hundreds) of specimens. The logarithmical plot of the rankabundance graph (Fig. 8) of the association collected at NYSM locality 5897 significantly differs from the trajectory of geometric, lognormal or logit distributions. Compared with an exponential distribution, the right-hand end of the trajectory of the Rochdale Formation abundance plot at Smith Basin is underrepresented, and the left-hand tail is over-represented. This pattern is very similar to the abundance plot of the Tribes Hill Formation cephalopods at Smith Basin (Kröger \& Landing, 2007, fig. 6) and illustrates that both associations are strongly dominated by a few genera.

The Simpson evenness index of the Tribes Hill Formation association $(D=3.29)$ is clearly higher than that from the Rochdale Formation $(D=2.39)$. The most common genus of the Tribes Hill Formation is 
Table 2. Comparison of successive Early Ordovician nautiloid associations of the Tribes Hill Formation (Skullrockian, NYSM locality 5896) and Rochdale Formation (Stairsian, NYSM locality 5897) at the Smith Basin section, Washington County, New York

\begin{tabular}{|c|c|c|c|c|c|}
\hline & $\begin{array}{l}\text { Sampled genera } \\
\qquad\left(\mathrm{S}_{\mathrm{obs}}\right)\end{array}$ & $\begin{array}{l}\text { Chao1 richness } \\
\qquad\left(\mathrm{S}_{\text {Chao1 }}\right)\end{array}$ & $\begin{array}{l}\text { Lower boundary } \mathrm{S}_{\mathrm{Chao}} \\
95 \% \text { conf. interval }\end{array}$ & $\begin{array}{l}\text { Simpson } \\
\text { index (D) }\end{array}$ & $\begin{array}{c}\text { Taxonomic } \\
\text { distinctness }\left(\Delta^{+}\right)\end{array}$ \\
\hline Rochdale Fm. (Stairsian) & 8 & 10 & 8 & 2.39 & 2.35 \\
\hline Tribes Hill Fm. (Skullrockian) & 11 & 13 & 11 & 3.29 & 1.20 \\
\hline
\end{tabular}

Ectenolites Ulrich \& Foerste, 1935, while Bassleroceras Ulrich \& Foerste, 1935 is the most common genus in the Rochdale Formation.

The richness of both associations is very similar. The Tribes Hill Formation at Smith Basin yielded 11 genera, and the Rochdale Formation yielded 8 genera. The Chao 1 richness (a standardized richness estimate; see Section 2) is 13 for the Tribes Hill Formation and 10 for the Rochdale Formation at Smith Basin (Table 2). Thus, the richness difference between the Tribes Hill and Rochdale formations at Smith Basin is only minor.

By contrast, the disparity between the two associations differs dramatically. The high discrepancy in disparity of the two associations is best expressed by the taxonomic distinctness index $\left(\Delta^{+}\right)$in this context. The taxonomic distinctness of the Rochdale Formation at NYSM locality $5897\left(\Delta^{+}=2.25\right)$ is nearly double that of the Tribes Hill Formation at NYSM locality $5896\left(\Delta^{+}=1.2\right)$. The discrepancy between the two stratigraphic intervals is more evident when comparing the cephalopods of the Tribes Hill Formation with those of the Rochdale Formation. In the Rochdale Formation, large endoceridans and tightly coiled tarphyceridans make their appearance.

\section{Cephalopod phylogeny}

\section{6.a. Origin of the Endocerida}

Endoceridans appear seemingly simultaneously in several regions of Laurentia in carbonates of the Stairsian Low Diversity Interval (conodonts). From the El Paso, Texas, region, Flower (1964b, 1969) reported the earliest endoceridans from the Victorio Hills Formation, which yields Low Diversity Interval conodonts (Repetski, 1982). In the Ibex area, western Utah, the first piloceratids are reported to occur at the base of the Fillmore Limestone (Flower, 1976), which is Stairsian (Ross et al. 1997). Proterocameroceratids, such as Proendoceras Flower, 1955 and Manitouoceras Ulrich et al. 1944, appear in the 'first endoceroid zone' of Flower $(1964 b, 1969)$ and slightly below the first occurrence of such pilocerids as Bisonoceras Flower, 1964c. Flower (1964a, p. 146) also reported a small, unnamed pilocerid from the 'first endocerid zone'. Ulrich et al. (1944) reported the proterocamerocerid Cotteroceras Ulrich et al. 1944, from the Roubidoux Formation in the Ozark region of Missouri. The Roubidoux spans the Low Diversity Interval-Macerodus dianae Zone (conodonts) and is approximately time- equivalent with the Rochdale Formation (Repetski, Loch \& Ethington, 1998; Landing, Westrop \& Van Aller Hernick, 2003). The Longview Limestone of Virginia from which Ulrich et al. (1944, p. 16) reported a number of pilocerids and proterocamerocerids is probably time-equivalent to the Rochdale Formation. In the Rochdale Formation, proterocameroceratids and piloceratids appear in the upper part of the lower member or low in the upper member.

Orthoceras primigenium Vanuxem, 1842, from the Tribes Hill Formation (Skullrockian), which was tentatively referred to Endoceras Hall, 1847 by Ulrich et al. (1944), is an ellesmerocerid. The species' holotype is lost, and specimens that were assigned to this species by later authors belong to Ectenolites Ulrich \& Foerste, 1935 (Flower, 1955, p. 344) and Ellesmeroceras Foerste, 1921 (Kröger \& Landing, 2007).

Whitfield (1889) illustrated bassleroceratids and endoceratids collected at a locality north of Beekmantown in northeastern New York that Ulrich et al. (1944, p. 18) referred to as the 'Beekmantown Limestone'. Endoceratidae, Protocyloceratidae and Tarphyceratidae are also reported from this prolific locality (Ulrich et al. 1944). Flower (1964a) discussed the locality as Demingian. However, Landing \& Westrop (2006) restudied Whitfield's (1889) locality, and illustrated much younger trilobites and conodonts characteristic of the Oepikodus communis-Fahraeusodus marathonensis Zone (conodonts) (Tulean-Blackhillsian, Floian). They also concluded that Whitfield's (1889) fauna has Stairsian trilobites, and could not have been collected at the locality north of Beekmantown, an area where the Rochdale Formation and Stairsian strata are absent at a Tribes Hill-Fort Cassin interformational unconformity. A remaining problem is that Whitfield's (1889) cephalopods from this locality north of Beekmantown are clearly of Fort Cassin aspect, which agrees with Landing \& Westrop's (2006) correlation of the locality, but further emphasizes that Whitfield's (1889) illustrated trilobites came from another locality.

Data on the stratigraphic context of the earliest endoceridans from Siberia and Baltoscandia are imprecise. However, Dideroceras leetsense Balashov, 1968 from the Leetse Formation in the Baltic Basin (Balashov, 1968, p. 143) and Proterocameroceras sibiricum Balashov, 1955 from Siberia are likely to be Floian in age or younger.

In conclusion, the available data now show that the earliest known endoceroids are from the Stairsian 


\begin{tabular}{|c|c|c|c|c|c|c|c|c|c|c|c|c|}
\hline & 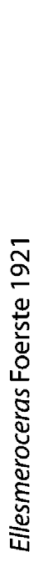 & 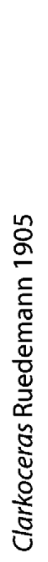 & 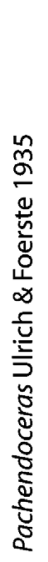 & 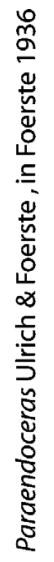 & 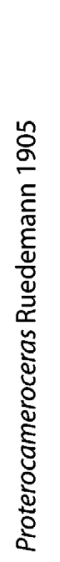 & 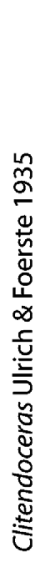 & 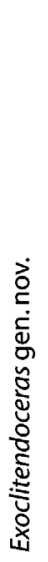 & 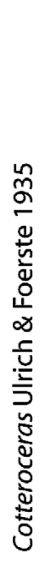 & 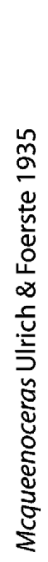 & 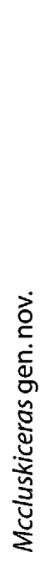 & 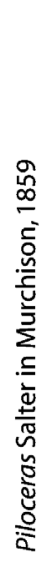 & 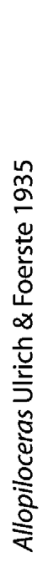 \\
\hline $\begin{array}{l}\text { Conch curvature } \\
\text { 1) cyrtocone endogastric, 2) straight, 3) exogastric }\end{array}$ & 2 & 1 & 2 & 2 & 2 & 2 & 3 & 2 & 1 & 1 & 1 & 1 \\
\hline $\begin{array}{l}\text { conch length } \\
\text { 1) brevicone, 2) longicone }\end{array}$ & 2 & 1 & 2 & 1 & 2 & 2 & 2 & 2 & 2 & 1 & 1 & 1 \\
\hline $\begin{array}{l}\text { 1) compressed, 2) circular, 3) depressed } \\
\text { cons section }\end{array}$ & 1 & 1 & 3 & 3 & 3 & 3 & 3 & 1 & 1 & 1 & 1 & 1 \\
\hline $\begin{array}{l}\text { Septa } \\
\text { 1) straight transverse, 22 oblique }\end{array}$ & 2 & 2 & 1 & 1 & 1 & 2 & 2 & 2 & 2 & 2 & 2 & 2 \\
\hline $\begin{array}{l}\text { sutures } \\
\text { 1) straight, 2) ventral lobe, 3) lateral lobe }\end{array}$ & 3 & 3 & 1 & 1 & 1 & 1 & 1 & 1 & 2 & 3 & 3 & 3 \\
\hline $\begin{array}{l}\text { septal neck shape } \\
\text { 1) achoanitic, 2) loxochoantitic 3) orhochoantic }\end{array}$ & 2 & 2 & ? & 2 & 3 & 2 & 2 & 2 & 2 & 2 & 2 & 2 \\
\hline $\begin{array}{l}\text { septal neck length } \\
\text { 1) achoonitic, 2) short, 3) hemit, 4) holochoantic }\end{array}$ & 2 & 2 & ? & 3 & 2 & 3 & 3 & 3 & 3 & 3 & 4 & 4 \\
\hline $\begin{array}{l}\text { segments siphotube } \\
\text { 1) concave, 2) tubular }\end{array}$ & 1 & 1 & 1 & 1 & 1 & 1 & 1 & 1 & 1 & 1 & 1 & 1 \\
\hline $\begin{array}{l}\text { endosiphuncular deposits } \\
\text { 1) absent, 2) endoconoses }\end{array}$ & 1 & 1 & 1 & 2 & 2 & 2 & 2 & 2 & 2 & 2 & 2 & 2 \\
\hline $\begin{array}{l}\text { central canal } \\
\text { 1) absent, 2) present }\end{array}$ & 1 & 1 & 1 & 2 & 2 & 1 & 2 & $?$ & 1 & $?$ & 2 & 2 \\
\hline $\begin{array}{l}\text { endosiphoblades } \\
\text { 1) absont, 2) prosent }\end{array}$ & 1 & 1 & 1 & 1 & 2 & $?$ & 1 & $?$ & $?$ & $?$ & 1 & 1 \\
\hline
\end{tabular}

Figure 9. Character matrix of selected Tremadocian ellesmerocerids and endocerids. A parsimony analysis of the dataset was conducted with Ellesmeroceras Foerste, 1921 as the outgroup and characters 7 (septal neck length) and 9 (endosiphuncular deposits) defined as 'ordered irreversible up'. The branch-and-bound search algorithm produced 43 equally parsimonious trees. The strict consensus tree of these 43 trees shows no resolution, only Piloceras Salter in Murchison, 1859 and Allopiloceras Ulrich \& Foerste, 1936 form a cluster. The analysis shows that the distinction of two early endocerid families is problematical because several alternative possibilities of transitional stages between Piloceras and Proterocameroceras exist. Moreover, on the basis of current knowledge, it is not possible to reconstruct an unambiguous phylogeny that leads from ellesmerocerids to the two Tremadocian endocerid morphotypes.

strata of Laurentia. Traditionally, the endocerids are thought to have derived from Pachendoceras Ulrich \& Foerste, 1935, or similar ellesmeroceratids (Flower, 1955). Pachendoceras is known from the Skullrockian Gasconade Dolostone of Missouri (Ulrich \& Foerste, 1935). Flower $(1955,1976)$ argued for the descent of the Piloceratidae from the Proterocameroceratidae and for the Endocerida as a monophyletic group with Pachendoceras as the ancestor. Dzik (1984, p. 26) questioned Flower's opinion, and argued that piloceratids may stem from a breviconic cyrtocone ellesmerocerid such as Clarkoceras Ruedemann, 1905. Dzik's (1984) main argument is the alleged appearance of piloceratids before proterocameroceratids. It is not clear where Dzik (1984) obtained this information, but Flower's records $(1964 b, 1969)$ indicate an appearance of proterocameroceratids before piloceratids or simultanously in the El Paso, Texas, and Ibex area, Utah, sections.

The new data from the Rochdale Formation cannot help to answer the question of endocerid monophyly, but they give some additional information on the morphological variation of the Endocerida in this critical time interval. In the Rochdale Formation, two endoceridans occur that are morphologically intermediate between the piloceratids and proterocameroceratids. These include Mcqueenoceras Ulrich \& Foerste, 1935 and Paraendoceras Ulrich \& Foerste in Foerste, 1936. A parsimony analysis of selected early endoceridans, including Paraendoceras and slender 'piloceratids', with the branch-and-bound algorithm produces 43 equally most parsimonous trees (Fig. 9). A consensus tree provides no resolution. Moreover, the parsimony analysis reveals that a separation between the Proterocameroceridae and Piloceratidae in the Stairsian is hardly possible. The slender, compressed cyrtoconic Mcqueenoceras and the short orthoconic Paraendoceras wappingerense (Ulrich et al. 1944), a form with compressed early growth stages, cluster in most of the most parsimonous trees with Piloceras Salter in Murchison, 1859 or, alternatively with Proterocameroceras Ruedemann, 1905. Therefore, an 
evolutionary transition between slender, orthoconic proterocamerocerids and compressed breviconic pilocerids and a monophyly of the Endocerida is conceivable.

Both families have a wide siphuncle and heavy endosiphuncular structures. These characters had evolved by the earliest Stairsian. In contrast, the holochoanitic septal necks and the tubular siphuncular segments are characters that evolved later in the Stairsian-Tulean (Floian) in proterocamerocerids, leading to the Endoceratidae. The septal necks of pilocerids are holochoanitic. However, Mcqueenoceras, which is morphologically intermediate between typical proterocamerocerids and pilocerids, has hemichoanitic septal necks. Therefore, it is probable that the morphological transformation from ellesmeroceridlike concave segments and short, often loxochoanitic, septal necks toward advanced tubular segments and holochoanitic septal necks occurred independently within breviconic and longiconic proterocamerocerids, giving rise to the pilocerids and endocerids.

This trend points to a functional value of septal neck prolongation within the Endocerida, and in fact, such a functional value can be deduced when comparing endoceridans with other cephalopods with holochoanitic septal necks. The elongation of the septal neck reduced the contact surface between the connecting ring and the volume of the free chamber. Kröger (2003) argued that a large contact surface causes an increased liquid backflow from the siphuncle in the cameral space during buoyancy maintenance, and that the reduction of the camera-siphuncle contact inhibits a liquid backflow. Thus, a wide siphuncle and long septal necks allowed a high control over liquid transport via the siphuncular epithelium and a minimized liquid backflow at the same time, increasing the efficiency of buoyancy regulation. In the case of early endoceridans with their greatly increased siphuncular surface, the subsequent reduction of the siphuncular contact surface with the free chamber volume would have provided a clear functional benefit. Additionally, the long septal necks greatly strengthened the wall of the widened siphuncle. Therefore, the holochoanitic septal necks in endocerids and pilocerids can be interpreted as a consequence of the widened siphuncle of proterocamerocerids. However, more data on the exact stratigraphic occurrences of the earliest pilocerids are needed to test this hypothesis.

\section{6.b. Origin of the Tarphycerida}

The derivation of the Tarphycerida from the bassleroceratids is undisputed (Flower, 1976; Dzik, 1984). Bassleroceratid conchs are slender cyrtocones with a marginal siphuncle of ellesmeroceridan aspect located along the convex side of the curved conch. Bassleroceratidae have the typical concave siphuncular shape (see Kröger \& Mutvei, 2005) of the Ellesmerocerida. Therefore, the Bassleroceratidae are referable to the Ellesmerocerida in the strict sense. Tarphyceratids differ in having a tubular siphuncle and typically a coiled shell (Furnish \& Glenister, 1964b).

Bassleroceratids appeared in the Stairsian. Their earliest records are from the Roubidoux Formation (Ulrich et al. 1944) and from the middle Rochdale Formation (this report). Earlier records from the Skullrockian Stonehenge Formation of Virginia are dubious at best. The specimens from the Stonehenge Formation assigned to the Bassleroceratidae by Unklesbay \& Young (1956) are strongly tectonically deformed, diagenetically altered and likely represent an ellesmerocerid taxon.

Flower (1969) listed the loosely coiled tarphyceridan Aphetoceras Hyatt, 1894, from the lower Fillmore Formation of Utah (shelly fossil zone D of Hintze, 1953; = Low Diversity Interval (conodonts); compare Ross et al. 1997) and the tightly coiled Campbelloceras Ulrich \& Foerste, 1935 from slightly higher beds of shelly fossil zone $\mathrm{E}$ of the Fillmore Formation (Macerodus dianae Zone). Aphetoceras occurs in the upper third of the Rochdale Formation at NYSM locality 5928 within the late Stairsian M. dianae Zone, and Campbelloceras was collected by R. H. Flower in Washington County and by D. W. Dwight from the upper Rochdale Formation (informal 'upper thrombolite member').

The nearly simultaneous occurrence of bassleroceratids, the openly coiled Aphetoceras and the tightly coiled Campbelloceras in the Rochdale Formation give evidence for a rapid evolutionary transition from the Ellesmerocerida to the Tarphycerida at the Skullrockian-Stairsian boundary or slightly higher. A similarly abrupt transition from straight bactritoids to coiled ammonoids is observed in the Early Devonian Pragian-Zlichovian boundary beds (Kröger \& Mapes, 2007). The reason(s) for the seemingly rapid evolution of coiled forms remains enigmatic, although the simultaneous appearance of durophagous predators may have played an important role (Kröger, 2005). Indeed, strong evidence of durophagous predation on cephalopods is reported from the lower Middle Ordovician (Darriwilian) strata of Baltoscandia (Kröger, 2004).

\section{6.c. Earliest Protocycloceratidae and origin of the Orthocerida}

Protocycloceratidae are here defined as annulated longicones with narrow marginal-subcentral siphuncles with concave siphuncular segments and thick connecting rings. Protocycloceratidae have endosiphuncular diaphragms and lack the typical lateral lobe of other Ellesmerocerida. The family reaches a diversity maximum in the Arenigian (Flower, 1964a). The report of Protocycloceras doniphorense Ulrich et al. 
1944 in the Roubidoux Formation would imply a first occurrence of Protocycloceras in the Stairsian. However, $P$. doniphorense differs considerably from the type of Protocycloceras in having a clearly narrower septal spacing and a broad marginal siphuncle. Thus, it probably represents an endocerid. The middle Ibexian reports of Protocycloceras are all based on specimens from the Spellman and Kirby ledge localities near Beekmantown in NE New York (Whitfield, 1889; compare Flower $1964 a$, pp. 127, 132). As discussed above, Landing \& Westrop (2006) reported trilobites and conodonts characteristic of the Oepikodus communis-Fahraeusodus marathonensis Zone (conodonts) (Tulean-Blackhillsian, Floian) from this area. Therefore, it can be concluded that the first unambiguous Protocycloceras Hyatt, 1900 occurs in the younger Fort Cassin Formation (Tulean-Blackhillsian, Floian) of eastern Laurentia and in coeval beds throughout Laurentia (Ulrich et al. 1944).

Protocycloceratids have such similarities with the Orthocerida as a slender straight conch and a narrow siphuncle. As in the Orthocerida, the septa are relatively widely spaced and have nearly straight sutures. Protocycloceratids differ from the Orthocerida in having a broad connecting ring with concave siphuncular segments. In Orthoceras Brugiere, 1789, the siphuncular segments are tubular and have a thin connecting ring. Therefore, protocycloderids are intermediate between the Ellesmerocerida and Orthocerida, and it has been suggested that protocyclocerids are ancestors of the Orthocerida (e.g. Flower, 1976).

However, the enigmatic Vassaroceras henrietta (Dwight, 1884) from the Rochdale Formation offers an alternative hypothesis. As described below, the marginal siphuncle of Vassaroceras Ulrich et al. (1944) is thin and probably tubular with a thin connecting ring similar to that in orthocerids. However, the narrow septal spacing and the lateral sutural lobes are ellesmerocerid characters, which also clearly differ from those of Protocycloceras.

Consequently, two alternative phylogenetic pathways from straight ellesmerocerids to Orthoceras are equally possible. The first would feature a reduction of the relative siphuncular diameter, a straightening of the sutures, and an increase in interseptal distance giving rise to protocyclocerids and a subsequent reduction of connecting ring thickness and the evolution of tubular siphuncular segments that characterize orthocerids. Alternatively, a second phylogenetic pathway can be reconstructed that is independent from the evolution of protocyclocerids, beginning with a reduction in connecting ring thickness and evolution of tubular segments already by the Stairsian (e.g. in Vassaroceras), and a subsequent straightening of the sutures and an increase in interseptal distance that lead finally to the appearance of the orthocerids independent of protocyclocerids. Indeed, the second scenario appears increasingly attractive with the recent discovery of the earliest orthocerids in the equivalents of TuleanBlackhillsian, Floian (Evans, 2005).

\section{Conclusions}

Revision of the Rochdale Formation in eastern New York indicates that it has 18 known species referred to 15 genera assigned to the Ellesmeroceratidae, Bassleroceratidae, Eothinoceratidae, Proterocameroceratidae, Piloceratidae, Estonioceratidae and Tarphyceratidae. Our restudy of the Rochdale Formation shows that the middle-upper part of the formation yields the earliest (Stairsian Stage, late Tremadocian) bassleroceratids, endoceridans and tarphyceridans.

The cephalopods of the Rochdale Formation occur in a depositional setting nearly identical to that of the middle-upper part of the underlying Tribes Hill Formation (Skullrockian, late early Tremadocian). The cephalopod associations of both formations occur in shallow-marine, carbonate platform facies with thrombolitic build-ups. Thus, the faunas of the Tribes Hill and Rochdale formations, respectively, record the first great expansions of the cephalopods with an initial diversification of small ellesmeroceratids in the late early Tremadocian, followed by bassleroceratids and the oldest representatives of the Endoceratida and Tarphyceratida with a wider variety of shell structures and significantly greater sizes in the late Tremadocian (e.g. Frey et al. 2004).

The cephalopod associations of the Tribes Hill and Rochdale formations are characterized by a low evenness. Although the Tribes Hill Formation evenness is slightly higher, in both formations a few taxa strongly dominate the associations. The richness of the Tribes Hill and the Rochdale formations are nearly identical. However, the taxonomic distinctness of the Rochdale Formation is twice that of the Tribes Hill Formation, and reflects a dramatically increased disparity of the Rochdale cephalopods. The cephalopods of the Rochdale Formation are, on average, clearly larger than those of the Tribes Hill Formation. The largest cephalopod specimens from the Tribes Hill Formation have a conch length of no more than about $100 \mathrm{~mm}$, but the conch of several endoceridans of the Rochdale Formation was clearly more than $200 \mathrm{~mm}$ long. The dramatically increased taxonomic distinctness, and the larger size of the cephalopods of the Rochdale Formation records the onset of the Ordovician Radiation of cephalopods in Laurentia.

\section{Systematic palaeontology}

All specimens are reposited in the New York State Museum (NYSM) Paleontology Collection.

\footnotetext{
Order ELLESMEROCERIDA Flower in Flower \& Kummel, 1950

Family BASSLEROCERATIDAE Ulrich et al. 1944

Genus Bassleroceras Ulrich \& Foerste, 1935
} 
Type species. Orthoceras perseus Billings, 1865, from St. Armand Limestone near Phillipsburg, Missisquoi County, Quebec, Canada.

Diagnosis. Bassleroceratids with slender curved, often compressed conch. Conch surface smooth or weakly undulated. Siphuncle marginal or submarginal on convex side of conch curvature. Prosiphuncular side more narrowly rounded than antisiphuncular side. Sutures curve downward laterally, have conspicuous lateral lobes. Siphuncle diameter approximately 0.1 times dorsoventral diameter. Siphuncular segments concave, septal necks orthochoanitic (after Ulrich \& Foerste, 1935, p. 263; Furnish \& Glenister, 1964a, p. K148).

Discussion. The Rochdale nautiloid Oncoceras vasiforme Dwight, 1884, subsequently assigned to Cyclostomiceras Foerste, 1925 by Ulrich, Foerste \& Miller (1943, p. 58), represents a Bassleroceras. The type specimens of Oncoceras vasiforme, which are reposited in the NYSM, feature oblique sections through cyrtoconic Bassleroceras conchs, and suggest an oncoceratoid conch. Flower (1964a, p. 124) earlier reached this conclusion. Their assignment to Bassleroceras is supported by their narrow marginal siphuncle, a characteristic feature of Bassleroceras, which is visible on the convex conch margin of specimen NYSM 17467.

Ulrich et al. (1944) described and illustrated Bassleroceras clelandi Ulrich et al. 1944 from the Tribes Hill Formation east of Fort Hunter in Montgomery County, New York, on the basis of one poorly preserved specimen. This species would be the earliest known Bassleroceras. However, the holotype does not show the siphuncular position and shape (compare Ulrich et al. 1944, p. 36) that are crucial for generic assignment. Further study of the specimen is impossible because it could not be located. Therefore, B. clelandi should be disregarded until more information is available. In conclusion, the earliest reliable occurrence of Bassleroceras is from the Stairsian Rochdale Formation and coeval units elsewhere in Laurentia.

Occurrence. Late Tremadocian (Stairsian)-early Darriwilian? of Laurentia, Siberia and East Gondwana (Australia and China).

\section{Bassleroceras champlainense sp. nov.} Figures 10a, b, 11

Holotype. NYSM 17468 collected by R. H. Flower from NYSM locality 5897, Stairsian, upper Rochdale Formation, Smith Basin section, Washington County, New York (Fig. 10a, b).

Paratypes. NYSM 17469, 17475 collected by R. H. Flower from NYSM locality 5897, Stairsian, upper Rochdale Formation, Smith Basin section, Washington County, New York.

Additional material. 57 additional specimens from NYSM locality 5897 (Smith Basin section) and six specimens from NYSM locality 5928 (Comstock section), Stairsian, upper Rochdale Formation, Washington County, New York; collected by R. H. Flower.

Diagnosis. Bassleroceras species with slightly curved conch, smooth shell surface and ovate, strongly compressed cross-section. Prosiphuncular conch margin is distinctively narrowly rounded and angular. Ratio of conch width/height is about 0.7, angle of expansion less than $5^{\circ}$. Sutures with conspicuous sharp saddle on prosiphuncular side, lateral lobes and shallow saddle on antisiphuncular side. Approximately 15 septa occur in a length comparable to conch height. Septal necks loxochoanitic, forming sharp right angle to septa. Siphuncle marginal on convex side of curved conch curvature, with diameter approximately 0.1 times conch cross-section. Siphuncular segments concave.

Etymology. champlainense (L.); the species was first recognized in the southern Lake Champlain lowlands of eastern New York.

Description. Holotype (NYSM 17468) (Fig. 10a, b) has total length of $97 \mathrm{~mm}$, conch width 16-22 mm, conch height $26-32 \mathrm{~mm}$, and includes part of the phragmocone and complete length of a body chamber. Conch is slightly curved with siphuncle marginal at convex side of growth axis. Adoral chambers with reduced interseptal distance show that the specimen reached maturity. Angle of expansion approximately $5^{\circ}$. Conch cross-section is strongly compressed and egg-shaped with maximum conch width close to the antisiphuncular conch margin. Prosiphuncular conch margin narrow and angular. Position of adoralmost septum is at conch height of $29 \mathrm{~mm}$. Length of body chamber $41 \mathrm{~mm}$. Adoralmost $10 \mathrm{~mm}$ of body chamber with strongly increased angle of expansion. Shell thickening occurs $10 \mathrm{~mm}$ from aperture, where shell thickness is $1.8 \mathrm{~mm}$. Shell thickness at apical end of specimen is $0.9 \mathrm{~mm}$. Shell surface smooth. Interseptal distance $1.8 \mathrm{~mm}$ at apical end, adoralmost septa with distance of $1.3 \mathrm{~mm}$. Septa are slightly oblique and slope in adoral direction at prosiphuncular side. Sutures form acute, distinctive saddle on prosiphuncular side, with shallow saddle on antisiphuncular side, and shallow but distinctive lateral lobe. Siphuncular diameter at apicalmost septum is $2.9 \mathrm{~mm}$ (approximately 0.11 of conch height).

Growth lines on specimen NYSM 17469 show that the aperture was nearly straight and transverse, but with a shallow sinus on the antisiphuncular (concave) side. NYSM 17469 shows that the growth lines form a subordinate, narrow, sharp, $\mathrm{V}$-shaped sinus on the antisiphuncular side.

Comparison. Bassleroceras champlainense sp. nov. differs from $B$. vassarina in having a more compressed conch crosssection and in lacking an antisiphuncular lobe. Bassleroceras perseus differs in having a less curved conch and a lower angle of expansion, and B. beekmanense Whitfield, 1889 differs in having a less curved conch.

Occurrence. Rochdale Formation, Stairsian, middle Early Ordovician of Washington County, southern Lake Champlain lowlands, New York.

\section{Bassleroceras smithbasinense sp. nov.} Figure $10 \mathrm{c}-\mathrm{f}$

Holotype. Holotype NYSM 17473 from NYSM locality 5897 (Smith Basin section), upper Rochdale Formation, Stairsian, middle Early Ordovician, Washington County, New York; collected by R. H. Flower (Fig. 10d-f).

Paratypes. Two additional specimens (NYSM 1747417475) from NYSM locality 5897 Smith Basin section), Stairsian, middle Early Ordovician, Washington County, New York; collected by R. H. Flower.

Diagnosis. Bassleroceras species with curved conch, smooth shell surface, and elliptically compressed crosssection. Prosiphuncular conch margin slightly more narrowly rounded than antisiphuncular conch margin. Conch 


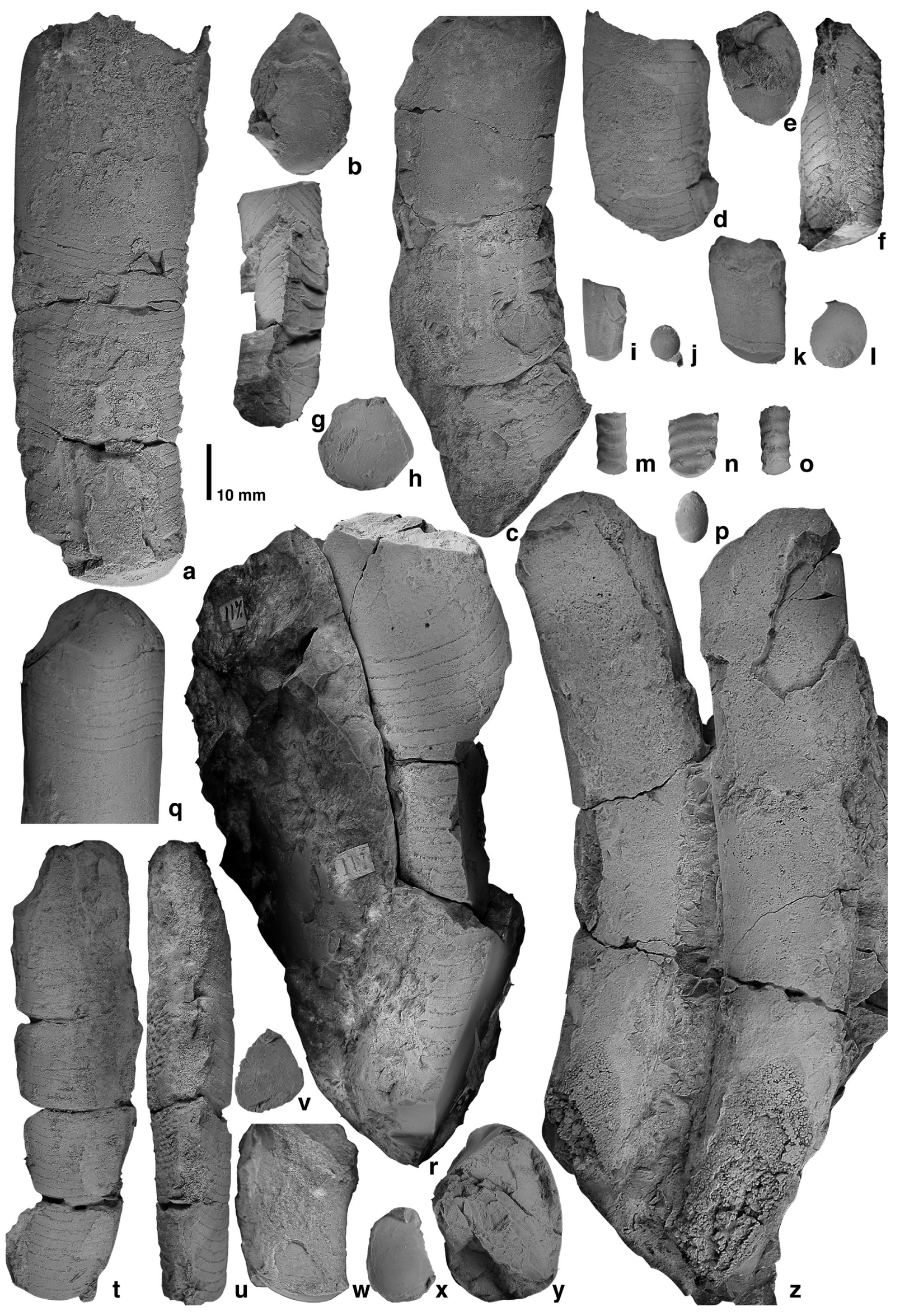

Figure 10. For legend see facing page. 


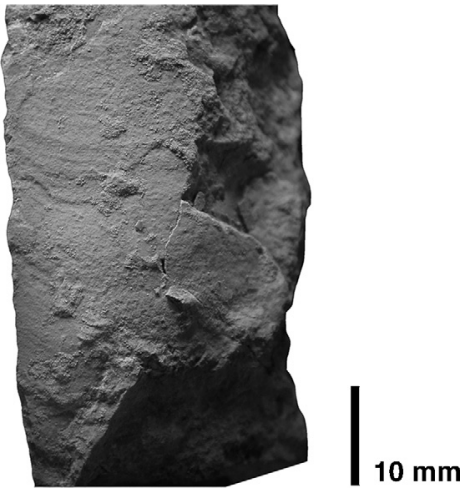

Figure 11. Bassleroceras champlainense sp. nov. (NYSM 17469) from NYSM locality 5897, Rochdale Formation (Stairsian). Conch surface of specimen is lightly irregularily undulated and displays growth lines. Scale bar $10 \mathrm{~mm}$.

width/height ratio about 0.7 , angle of expansion is about $7^{\circ}$ in juvenile growth stages and less than $5^{\circ}$ in later ontogenetic stages. Sutures with conspicuous sharp saddle on prosiphuncular side, lateral lobes and shallow saddle on antisiphuncular side. Approximately 11-15 septa in a length similar to conch height. Septal necks loxochoanitic, forming sharp right angle to septa. Siphuncle marginal on convex side of conch, diameter approximately 0.1 times conch crosssection. Siphuncular segments concave.

Etymology. smithbasinense (L.); the species was first recognized in the Smith Basin section, Washington County, New York.

Description. Holotype NYSM 17473 (Fig. 10d-f) is a phragmocone fragment with a total length of $32 \mathrm{~mm}$, conch width 13-14 mm, and conch height 19-20 mm. Angle of expansion less than $5^{\circ}$. Conch clearly curved, with siphuncle marginal in position on the convex side of the conch growth axis. Conch cross-section is strongly compressed ellipse, with maximum conch width close to the dorsoventral midlength. Prosiphuncular conch margin slightly more narrow and angular than antisiphuncular margin. Septa oblique, slope in adoral direction on prosiphuncular side of conch. Distance between septa approximately $1.7 \mathrm{~mm}$. Sutures form distinct sharp saddle on prosiphuncular side, with shallow saddle on antisiphuncular side and a lateral lobe. Siphuncular diameter $1.7 \mathrm{~mm}$ at adoral end of fragment, with concave siphuncular segments. Septal necks loxochoanitic.

NYSM 17475 is a fragment of a juvenile conch with a height of 12.4-18 mm, and adapical width $7.6 \mathrm{~mm}$. Conch clearly curved, with $7^{\circ}$ angle of expansion. Eleven septa occur along a length comparable to conch height.

NYSM 17474 (Fig. 10c), the largest known specimen of the species, has a length of $78 \mathrm{~mm}$, maximum conch height of $26 \mathrm{~mm}$ and maximum width of $16 \mathrm{~mm}$. It is a phragmocone fragment with part of the body chamber. The conch crosssection is elliptically compressed with a maximum diameter close to the dorsoventral midlength. The adoralmost septa are crowded. The interseptal distance at the apical end of specimen is $2 \mathrm{~mm}$.

Comparison. Bassleroceras smithbasinense sp. nov. is in many aspects similar to $B$. champlainense sp. nov., but differs from the latter in having an elliptical cross-section with the maximum conch width near the conch centre. Bassleroceras perseus Billings, 1865 differs in having a less curved conch and a lower angle of expansion.

Occurrence. Upper part of the Rochdale Formation, Stairsian, middle Early Ordovician of Washington County, southern Lake Champlain lowlands, New York.

\section{Bassleroceras triangulum sp. nov. Figure $10 \mathrm{t}-\mathrm{V}$}

Holotype. NYSM 17477 from NYSM locality 5897 (Smith Basin section), upper Rochdale Formation, Stairsian, Washington County, New York; collected by R. H. Flower (Fig. 10t-v).

Paratype. NYSM 17478 from NYSM locality 5897, upper Rochdale Formation, Stairsian, Washington County, New York; collected by R. H. Flower.

Diagnosis. Bassleroceras species with slightly curved conch, smooth shell surface and triangular, strongly compressed cross-section. Prosiphuncular conch side angular, lateral conch sides flattened, antisiphuncular side flattened with maximum conch width. Conch width/height ratio about 0.7 , angle of expansion less than $5^{\circ}$. Sutures with conspicuous sharp saddle on prosiphuncular side, lateral lobes and shallow saddle on antisiphuncular side. Approximately 10 15 septa occur over a length similar to conch height. Siphuncle marginal on convex side of conch, with diameter approximately 0.1 times conch cross-section. Siphuncular segments concave.

Etymology. triangularum (L.); refers to the triangular crosssection.

Description. Holotype NYSM 17477 (Fig. 10t-v) is a phragmocone fragment with total length of $81 \mathrm{~mm}$, conch height of $16-21 \mathrm{~mm}$, and maximum width about $15 \mathrm{~mm}$.

Figure 10. Ellesmerocerida of the Rochdale Formation (Stairsian). Scale bar $10 \mathrm{~mm}$. (a, b) Bassleroceras champlainense sp. nov., holotype, (NYSM 17468) from NYSM locality 5897 in (a) lateral and (b) adapical view. (c-f) Bassleroceras smithbasinense sp. nov.; (c) specimen NYSM 17474 from NYSM locality 5897 in lateral view, (d-f) holotype (NYSM 17473) from NYSM locality 5897 in (d) lateral, (e) adapical, and (f) prosiphuncular view. (g, h) Bassleroceras sp. A; specimen NYSM 17483 from NYSM locality 5897 (g) in lateral view, (h) in adapical view. (i, j) Ectenolites sp. (NYSM 17487) from NYSM locality 5897 in (i) lateral and (j) adapical view. $(\mathrm{k}, 1)$ Dwightoceras dactyloides (Dwight, 1884) (NYSM 17486) from NYSM locality 5897 in (k) lateral and (1) adapical view. (m-p) Vassaroceras henrietta (Dwight, 1884), NYSM 17489 from NYSM locality 5897 in (m) antisiphuncular, (n) lateral, (o) prosiphuncular, and (p) adapical view. (q, r) Bassleroceras vassarina (Dwight, 1884); (q) specimen NYSM 10370, plesiotype collected by W. B. Dwight from Rochdale and figured by Ulrich et al. (1944, pl. 6, figs 7-12), antisiphuncular view; (r) holotype (NYSM 11423) collected by W. B. Dwight from Rochdale and figured by Dwight (1884, pl. 7, fig 7), lateral view. (t-v) Bassleroceras triangulum sp. nov. (NYSM 17477), holotype, from NYSM locality 5897 in (t) lateral, (u) prosiphuncular, and (v) adapical view, antisiphuncular part of adapical view not preserved in figure (v). (w-z) Bassleroceras vassarina (Dwight, 1884); (w, x) specimen NYSM 17479 from NYSM locality 5897 in (w) lateral and (x) adapical view, (y) adoral view of holotype (see above), (z) lateral view of specimens NYSM 17470-71. 
Angle of expansion is approximately $4^{\circ}$. Conch is slightly curved with siphuncle marginal on convex side. Conch crosssection triangular with angular prosiphuncular side, flattened lateral sides and flattened antisiphuncular side. Maximum conch width is at antisiphuncular side. Conch width/height ratio is 0.7 . Septa slope slightly obliquely in adoral direction on prosiphuncular side. Suture forms sharp, angular saddle on prosiphuncular side, with shallow, but distinctive, lateral lobes and shallow saddle on antisiphuncular side. Interseptal distance 1.4-2.3 mm. Siphuncular diameter at adapical end of specimen is $2.5 \mathrm{~mm}$.

NYSM 17478 is poorly preserved phragmocone fragment with a maximum conch height of $20 \mathrm{~mm}$, conch width of $12.6 \mathrm{~mm}$, and a total length of $39 \mathrm{~mm}$.

Comparison. Bassleroceras triangularum sp. nov. differs from all other Bassleroceras species in having a compressed, triangular conch cross-section.

Occurrence. Upper part of the Rochdale Formation, Stairsian, middle Early Ordovician of Washington County, southern Lake Champlain lowlands, New York.

\section{Bassleroceras vassarina (Dwight, 1884) emend. Figures $10 \mathrm{q}, \mathrm{r}, \mathrm{w}-\mathrm{z}, 13 \mathrm{~b}-\mathrm{d}$}

1884 Cyrtoceras vassarina Dwight, p. 254, pl. 7, figs 7, 8.

1915 Cyrtoceras vassarina Dwight; Bassler, p. 358.

1924 Cyrtoceras vassarina Dwight; Foerste, p. 207.

1944 Bassleroceras vassarina (Dwight); Ulrich et al., p. 40 , pl. 6, figs 7-12.

Holotype. NYSM 11423, collected by W. B. Dwight from the upper Rochdale Formation, Stairsian, middle Early Ordovician, at Rochdale, Dutchess County, New York (Fig. 10r). This specimen was collected by Dwight, and his original label notes 'No. 117, Cyrtoceras vassarina, calciferous group, Rochdale, Dutchess Co. N.Y., collected by W. B. Dwight in 3 pieces marked $117 \mathrm{a}, \mathrm{b} \&$ c'. On a second label is written 'Type. Fig. 7. Plate VII, Am. Journ. Science Vol. XXVII, 1884, W. B. Dwight'. The specimen figured by Dwight (1884, pl. 7.7) is highly idealized, but undoubtedly represents NYSM 11423, and is the holotype of this species.

Additional material. Five specimens (NYSM 10367, 10370, 17480-82) collected by W. B. Dwight from the upper Rochdale Formation, at Rochdale, Dutchess County, New York. Four specimens, NYSM 17470-71 and 17479, 17485 from NYSM locality 5897 (Smith Basin section), upper Rochdale Formation, Stairsian, middle Early Ordovician, Washington County, New York; collected by R. H. Flower.

Emended diagnosis. Cyrtoconic, longicone Bassleroceras species with smooth shell and compressed cross-section. Prosiphuncular conch margin more narrowly rounded, but not angular. Conch width/height ratio about 0.9 , angle of expansion approximately $6-7^{\circ}$. Sutures with conspicuous saddle on prosiphuncular side and lateral lobes, with shallow but conspicuous lobe on antisiphuncular side. Approximately 10-15 septa occur over a length similar to conch height. Septal necks loxochoanitic, form sharp right angle to septa. Siphuncle marginal on convex side of curved conch, with diameter approximately 0.1 times conch cross-section. Siphuncular segments concave.

Description. Holotype NYSM 11423 (Fig. 10r, y) comprises three fragments of the same specimen comprising a phragmocone and a body chamber with length of $110 \mathrm{~mm}$, a conch width of 15-24 mm and maximum height of $27.5 \mathrm{~mm}$ (angle of expansion of conch height is $6.5^{\circ}$ ). Conch cross-section a compressed oval with prosiphuncular side markedly angular and narrowed. Growth axis clearly curved with siphuncle at conch margin on convex side of conch. Outer shell with thickness of $1.7 \mathrm{~mm}$ at adoral end of specimen. Body chamber cyrtoconic and slightly undulated, with preserved length of $26.5 \mathrm{~mm}$. Faint longitudinal striae occur at base of mold of body chamber. Sutures form acute saddle on prosiphuncular side (convex side of conch) and form conspicuous shallow lobe on antisiphuncular side. Shallow but distinctive lateral lobe. Septa are slightly oblique, slope adorally on prosiphuncular side. Interseptal distance at base of body chamber $2.6 \mathrm{~mm}$. Approximately 12-13 chambers occur in a length comparable to conch height. Siphuncle in apical part of fragment has $3.4 \mathrm{~mm}$ diameter. Septal necks poorly preserved, but apparently loxochoanitic or orthochoanitic. Connecting ring thin with clearly concave segments.

NYSM 10367 (Fig. 13c) has length of $58 \mathrm{~mm}$, and adapical conch height of $21 \mathrm{~mm}$, conch width about $19 \mathrm{~mm}$ (angle of expansion $6^{\circ}$ ). Approximately eleven chambers occur in a length comparable to conch height. Siphuncle marginal on convex side of conch, with $2 \mathrm{~mm}$ diameter in apical part of fragment. Septal necks loxochoanitic, form a sharp right angle toward the septum, have a length of approximately $0.3 \mathrm{~mm}$ where interseptal distance is $2 \mathrm{~mm}$. Connecting ring thin, with concave siphuncular segments.

NYSM 17480 (Fig. 13d) has a well-preserved siphuncle and septal necks. It shows a thick connecting ring with concave segments and septal necks that are loxochoanitic and make a sharp right angle with the septum.

The largest specimen is NYSM 10370 (Fig. 10q) with a maximum conch height of $31 \mathrm{~mm}$ and a width of $26 \mathrm{~mm}$. It was described and figured by Ulrich et al. (1944, p. 41 , pl. 6, figs 11, 12). This specimen deviates from other specimens assigned to Bassleroceras vassarina in having a body chamber that is smaller in diameter than the apical portions of the conch.

NYSM 17479 (Fig. 10w, x) is a $29 \mathrm{~mm}$ long, 11.6$13.5 \mathrm{~mm}$ wide and $17.5-21 \mathrm{~mm}$ high fragment of the body chamber and two adoralmost chambers of the phragmocone that show a juvenile growth stage. The conch is more strongly curved than in later growth stages, and has the marginal siphuncle on the convex side. Conch width/height ratio approximately 0.65 . Conch cross-section compressed with flattened lateral sides, with angular prosiphuncular and rounded antisiphuncular sides. Maximum cross-section diameter is at midlength of dorsoventral axis.

Specimens NYSM 17470 and17471 are preserved on a single slab. Both specimens have a length of approximately $130 \mathrm{~mm}$, and a maximum diameter of approximately $27 \mathrm{~mm}$. The specimens differ slightly in conch cross-section. They are similar in having an egg-shaped, compressed cross-section with the maximum conch width close to the antisiphuncular conch margin, and a narrow, angular prosiphuncular conch margin. NYSM 17471 has a conch width/height ratio of 0.64 , and NYSM 17470 a ratio of 0.74 . In both specimens, the shell surface is slightly undulated, and the shell thickness is very great $(2.7 \mathrm{~mm}$ in NYSM 17470, $2.3 \mathrm{~mm}$ in NYSM 17471) at the adoral end.

Discussion. The emended diagnosis is based on a reexamination of the holotype and deviates from earlier 
diagnoses (Dwight, 1884; Ulrich et al. 1944) in a precise description of the distinctive antisiphuncular lobe. The deviation of the body chamber form of specimen NYSM 10370 is interpreted as an adult modification.

Comparison. Bassleroceras vassarina is distinguished from other species of Bassleroceras in having a comparatively smoothly rounded, oval cross-section and in having a distinctive shallow lobe on the antisiphuncular side of the conch.

Occurrence. Upper part of the Rochdale Formation, Stairsian, middle Early Ordovician at Rochdale, Dutchess County, and in Washington County, southern Lake Champlain lowlands, New York.

\section{Bassleroceras sp. A.} Figure $10 \mathrm{~g}, \mathrm{~h}$

Description. NYSM 17483 (Fig. 10g, h) is a phragmocone fragment with a total length of $44 \mathrm{~mm}$, conch width of about $14-17 \mathrm{~mm}$, and the height $10.5-13.7 \mathrm{~mm}$. Conch cross-section triangular. Prosiphuncular side angular, lateral and antisiphuncular sides flattened. Maximum cross-section diameter is on antisiphuncular side. Angular prosiphuncular side departs from bilateral axis of symmetry. An asymmetry exists because the prosiphuncular side is shifted toward the left margin apically, and shifted toward the right adorally. Siphuncle $10 \mathrm{~mm}$ from right conch margin apically, and $10 \mathrm{~mm}$ from left margin adorally. Siphuncle marginal on convex side of conch, with approximate $1.8 \mathrm{~mm}$ diameter. Interseptal distance about $1.8 \mathrm{~mm}$. Sutures oblique, slope adorally on prosiphuncular side. Sutures form distinctive, angular saddle on prosiphuncular side; lateral lobes and shallow saddle on antisiphuncular side.

A second specimen, NYSM 17484, has a length of approximately $70 \mathrm{~mm}$, of which the apical $25 \mathrm{~mm}$ shows the conch cross-section. At the apical end, the conch height is about $18 \mathrm{~mm}$, and the width is $17 \mathrm{~mm}$. Conch cross-section triangular with prosiphuncular side narrowed, angular; lateral and antisiphuncular sides flattened. Conch cross-section is bilaterally asymmetrical with angular prosiphuncular side and marginal siphuncle slightly shifted to the left aperturally. Distance of the centre of the siphuncle from the right conch margin at the adapical end is $9.5 \mathrm{~mm}$. Conch sightly curved with siphuncle on convex side of conch.

Discussion. An asymmetric conch is known from a number of Early Devonian oncoceridans (e.g. Bohemojovellania Manda, 2001). The general conch shape of these oncoceridans is very similar, and they include longicones with flattened venter, triangular shape and narrowly spaced septa. However, on the basis of the two poorly preserved specimens, it cannot be shown with certainty that the asymmetry is not an effect of diagenesis or taphonomy. The very similar Bassleroceras triangularum sp. nov. differs in having a more compressed cross-section.

Material. NYSM 17483 and 17484 from the upper Rochdale Formation at NYSM locality 5897 (Smith Basin section), Washington County, New York; collected by R. H. Flower.

Genus Dwightoceras Ulrich \& Foerste, 1935

Type species. Cyrtoceras? dactyloides Dwight, 1884, from the upper Rochdale Formation at Rochdale, Dutchess County, New York.

Diagnosis. Bassleroceratids with weakly compressed, slightly cyrtoconic longicone conchs with siphuncle marginal on convex side of conch. Septa slightly oblique, slope adorally on antisiphuncular side. Sutures have angular saddle on concave antisiphuncular side, shallow broad saddle on prosiphuncular side, and shallow lateral lobes. Siphuncle has circular cross-section and is not flattened along its area of contact with conch wall. Compared with the conch diameter, the siphuncle is relatively large (after Ulrich \& Foerste, 1935, p. 272).

Comparison. Dwightoceras differs from Avaoceras Ulrich et al. 1944 in having a compressed cross-section, and from Diaphoroceras Ulrich et al. 1944 in having a strictly marginal siphuncle.

Occurrence. Stairsian-early Darriwilian? of Laurentia, Siberia and East Gondwana (Australia and China).

Dwightoceras dactyloides (Dwight, 1884) Figure 10k, 1

1884 Cyrtoceras? dactyloides Dwight, p. 255, pl. 7, figs 9, 9 a.

1905 Cyrtoceras? dactyloides Dwight; Ruedemann, p. 508.

1915 Cyrtoceras? dactyloides Dwight; Bassler, p. 351.

1935 Dwightoceras dactyloides (Dwight); Ulrich \& Foerste, p. 272.

1944 Dwightoceras dactyloides (Dwight); Ulrich et al., p. 45 , pl. 1, figs 1-3.

Diagnosis. Same as for the genus.

Description. NYSM 17486 (Fig. 10k, 1) is a fragment of the body chamber and one chamber of the phragmocone. It has a length of $19 \mathrm{~mm}$, and maximum conch height of $15 \mathrm{~mm}$ and width of $12.5 \mathrm{~mm}$. Cross-section elliptically compressed with conch width/height ratio of 0.86 . Angle of expansion $9.6^{\circ}$. Conch very slightly curved with siphuncle marginal on convex side of conch. Conch surface smooth. Conch height at base of body chamber is $12.3 \mathrm{~mm}$. Septa oblique, slope in adoral direction on antisiphuncular side. Interseptal distance is $1.8 \mathrm{~mm}$. Sutures form distinct angular saddle on antisiphuncular side and shallow broad saddle on prosiphuncular side, have shallow lateral lobes. Siphuncular diameter at adapical end of fragment is $4.3 \mathrm{~mm}$ ( 0.35 times conch cross-section).

Discussion. This specimen represents only the second record of this species. Dwight's (1884) material came from Rochdale, Dutchess County, and NYSM 17486 was collected by R. H. Flower from the Smith Basin section in Washington County. This newly recognized specimen from the Rochdale Formation in the Lake Champlain lowlands supports the generic concept of Ulrich et al. (1944).

Material examined. NYSM 17486 from NYSM locality 5897 (Smith Basin section); collected by R. H. Flower.

Occurrence. Upper part of the Rochdale Formation, Stairsian, middle Early Ordovician at Rochdale, Dutchess County, and in Washington County, southern Lake Champlain lowlands, New York.

Family ELLESMEROCERATIDAE Kobayashi, 1934 Genus Ectenolites Ulrich \& Foerste, 1935

Type species. Ectenolites subgracilis Ulrich \& Foerste, 1935, from the Early Ordovician Gasconade Dolostone, Franklin County, Missouri. 
Diagnosis. Ellesmeroceratids with slender, slightly cyrtoconic conch with compressed cross-section and lateral sutural lobes. Logarithmically curved juvenile growth axis straightens within $5 \mathrm{~mm}$ of apex; apical angle very low, less than $5^{\circ}$. Conch smaller than in most longiconic Ellesmerocerida, with adult length less than $50 \mathrm{~mm}$. Outer shell smooth. Siphuncle marginal or slightly displaced from margin on concave side of the shell; rarely, mature conch slightly curved with siphuncle on convex side. Siphuncular segments concave, consist of thick connecting ring; septal necks short and orthochoanitic or achoanitic. Endosiphuncular diaphragms known (diagnosis after Flower, 1964a, p. 52).

Comparison. The growth axis in the younger parts of Ellesmeroceras conchs is always straight, as the logarithmically curved juvenile growth axis straightens about $10 \mathrm{~mm}$ from the apex. Walcottoceras Ulrich \& Foerste, 1935 and Rudolfoceras Ulrich et al. 1944 differ in having an annulated shell.

Occurrence. Latest Cambrian-Early Ordovician; Laurentia (including Greenland), North China.

\section{Ectenolites sp. \\ Figure 10i, j}

Description. The specimen is a fragment of the body chamber with two chambers of the phragmocone; its total length is $13.7 \mathrm{~mm}$, with adoral conch width of $5.7 \mathrm{~mm}$ and height of $7.8 \mathrm{~mm}$. Conch width at apical end $5.0 \mathrm{~mm}$, and conch height of $6.3 \mathrm{~mm}$ (angle of expansion $6.6^{\circ}$ ). Conch is nearly straight with cross-section elliptically compressed. Conch margins in median section have slightly convex shape. Distance between septa is $0.7 \mathrm{~mm}$. Suture forms broad, shallow lateral lobe. Siphuncle marginal at convex side of conch, with diameter of about $1.0 \mathrm{~mm}$ at apical end of specimen.

Discussion. The single specimen does not allow a specieslevel determination. However, the specimen probably is related to Ectenolites extensus Flower, 1964a from the Chepultapec Limestone in Virginia. The specimen differs from E. penicillin Flower, 1964a, which is known from the Tribes Hill Formation of eastern New York, in having a higher angle of expansion and a body chamber with clearly convex conch margins.

Material. One specimen, NYSM 17487, from the upper Rochdale Formation (Stairsian) from NYSM locality 5897 (Smith Basin section), Washington County, New York; collected by R. H. Flower.

Family indeterminate

Genus Vassaroceras Ulrich et al. 1944 emend.

Type species. Orthoceras henrietta Dwight, 1884, from the upper Rochdale Formation, at Rochdale, Dutchess County, New York.

Emended diagnosis. Ellesmeroceratidans with slender, slightly cyrtoconic conch with prominent annulations. The annulations are oblique, slope adorally on prosiphuncular side. Angle of expansion very low, less than $7^{\circ}$. Crosssection compressed, elliptical, with conch width/height ratio about 0.6. Prosiphuncular side narrower than antisiphuncular side. Septa slightly oblique, and slope parallel to annulations. Sutures have distinct lateral sutural lobe. Siphuncle marginal or slightly displaced from convex side of the shell. Connecting ring thin; septal necks short and orthochoanitic or achoanitic.
Discussion. Vassaroceras henrietta (Dwight, 1884), the type and sole species of the genus, was poorly known previously. Only a few, poorly preserved specimens exposed in longitudinal section were available. New material from the upper Rochdale Formation in the Lake Champlain lowlands reveals that the siphuncle is marginal on the convex side of the conch, and has concave or tubular segments. Therefore, Vassaroceras is closely related to Rudolfoceras, as proposed by Flower (1964a, p. 141).

Comparison. This genus differs from Rudolfoceras Ulrich et al. 1944 in having a strongly compressed cross-section. Ectocycloceras Ulrich et al. 1944 differs in having straight sutures and a thin marginal siphuncle. Walcottoceras Ulrich $\&$ Foerste, 1935, which is otherwise similar, differs in having a marginal siphuncle on the concave side of the conch.

The marginal siphuncle of Vassaroceras is thin and probably tubular with a thin connecting ring not typical for ellesmeroceridans. However, the narrow septal spacing and the lateral sutural lobes are ellesmerocerid characters. The genus is tentatively placed within the Ellesmerocerida. A new family must probably be erected for Vassaroceras, including ellesmeroceridans with thin siphuncular tube and thin connecting rings. The higher classification of Vassaroceras and protocyclocerids will be the subject of a future investigation including the early Arenigian protocyclocerids.

Occurrence. Upper part of the Rochdale Formation, Stairsian, middle Early Ordovician, eastern New York.

\section{Vassaroceras henrietta (Dwight, 1884)} Figures $10 \mathrm{~m}-\mathrm{p}, 13 \mathrm{e}, \mathrm{h}$

1884 Orthoceras henrietta Dwight, p. 256, pl. 7, figs 13$14 \mathrm{a}$.

1915 Orthoceras henrietta Dwight; Bassler, p. 907.

1924 Orthoceras henrietta Dwight; Foerste, p. 203.

1944 Vassaroceras henrietta (Dwight); Ulrich et al., p. 33, pl. 4, figs 1-6.

1964 a Vassaroceras henrietta (Dwight); Flower, pp. 129, 141.

Diagnosis. Same as for the genus.

Description. Specimen NYSM 17489 (only the body chamber is shown in Fig. $10 \mathrm{~m}-\mathrm{p}$ ) is a $35 \mathrm{~mm}$ long fragment of the phragmocone and part of the body chamber. The conch width at the adoral end is $5.4 \mathrm{~mm}$, and the conch height is $9.0 \mathrm{~mm}$. Conch width at adapical end is $3.8 \mathrm{~mm}$. Conch crosssection a strongly compressed ellipse with prosiphuncular side slightly more narrowed. Position of maximum conch width is at midlength of conch height. Annulations have a $2.0 \mathrm{~mm}$ spacing adorally. Annulations oblique, slope adorally on prosiphuncular side, and form shallow lateral projections. Septa oblique, slope parallel to annulations. Sutures form distinct saddles on pro- and antisiphuncular sides, and have lateral lobes. Interseptal distance approximately $1.0 \mathrm{~mm}$ where conch height is $8.0 \mathrm{~mm}$. Siphuncle marginal on convex side of conch (Fig. 13e), with $0.6 \mathrm{~mm}$ diameter where conch height is $8.0 \mathrm{~mm}$. Siphuncular segments slightly concave or tubular (Fig. 13h). Connecting ring thin. Septal necks short, orthochoanitic or achoanitic.

A second specimen, NYSM 17490, has a maximum conch height of approximately $7.6 \mathrm{~mm}$ and length of $12 \mathrm{~mm}$. Conch width approximately $4.0 \mathrm{~mm}$ at the adoral end of the specimen. Specimen shows no traces of sutures.

The third specimen, NYSM 17488, is an oblique longitudinal section of parts of a phragmocone with a length of 
$26 \mathrm{~mm}$, and maximum conch height of $11 \mathrm{~mm}$. The spacing of the annulations at the adoral end is approximately $2.5 \mathrm{~mm}$.

Material examined. Two of the specimens, NYSM 17489 and 17490, were collected at NYSM locality 5897 (Smith Basin) by R. H. Flower. Kröger \& Landing collected an additional specimen, NYSM 17488, $16.0 \mathrm{~m}$ above the base of the Rochdale Formation at the Comstock section (sample Com-R-16.0 m).

Occurrence. Upper Rochdale Formation, Stairsian, middle Early Ordovician, in Washington County, southern Lake Champlain lowlands, New York.

Order ENDOCERIDA Teichert, 1933

Family PROTEROCAMEROCERATIDAE Kobayashi, 1937

Genus Clitendoceras Ulrich \& Foerste, 1935

Type species. Clitendoceras saylesi Ulrich \& Foerste, 1935, from the Fort Cassin Formation (Tulean-Blackhillsian, Floian), near Whitehall, Washington County, New York.

Diagnosis. Protocameroceratid genus known from slender orthoconic conchs with circular or slightly compressed crosssection. Siphuncle marginal on concave side of conch. Sutures straight and directly transverse, slope adorally on antisiphuncular side. Septal necks short in early growth stages, hemichoanitic-subholochoanitic in later growth stages. Siphuncular segments slightly concave; siphuncle circular in cross-section. Endocones project adorally on siphuncular side that faces conch wall. Internal mold of endocone flattened (after Flower, 1956, p. 87).

Discussion. In Clitendoceras, the siphuncle is on the concave side of the conch, and the annuli slope adorally toward the conch wall. These features are similar to those in the Piloceratidae and in Mcqueenoceras. However, the systematic significance of these characters is not understood. It may be noted that Flower (1956, p. 93) emphasized the similarity between Mcqueenoceras and Clitendoceras, and inferred a close relationship between the two genera. Mcqueenoceras and Clitendoceras probably represent a group of slender endogastric Stairsian endoceridans that gave rise to exogastric and straight Proterocameroceratidae and the Endoceratidae during the Stairsian.

Comparison. Clitendoceras differs from Mcqueenoceras in having straight sutures, a nearly central endosiphotube and a circular or depressed conch cross-section. Proterocameroceras Ruedemann, 1905 and Proendoceras Flower, 1955 have an overall similar general conch form, but differ in having a marginal siphuncle on the convex side of the conch and in the shape of the speculum. In Proendoceras, the siphuncular segments are slightly bulbous and the endosiphuncular annuli slope apically on the side that faces the conch wall. The conch of the otherwise similar Cotteroceras Ulrich \& Foerste, 1935 is straight and has a compressed cross-section.

Occurrence. Stairsian-Blackhillsian (upper Tremadocianearly Arenigian); Laurentia, Siberia, China.

\section{Clitendoceras saylesi Ulrich \& Foerste, 1935}

Figures 12e, 13k, 14f, g, j, k

1935 Clitendoceras saylesi Ulrich \& Foerste, p. 268, pl. 38 , fig. 1.

1944 Clitendoceras saylesi Ulrich \& Foerste; Ulrich et al., p. 106, pl. 26, figs $1-3$.

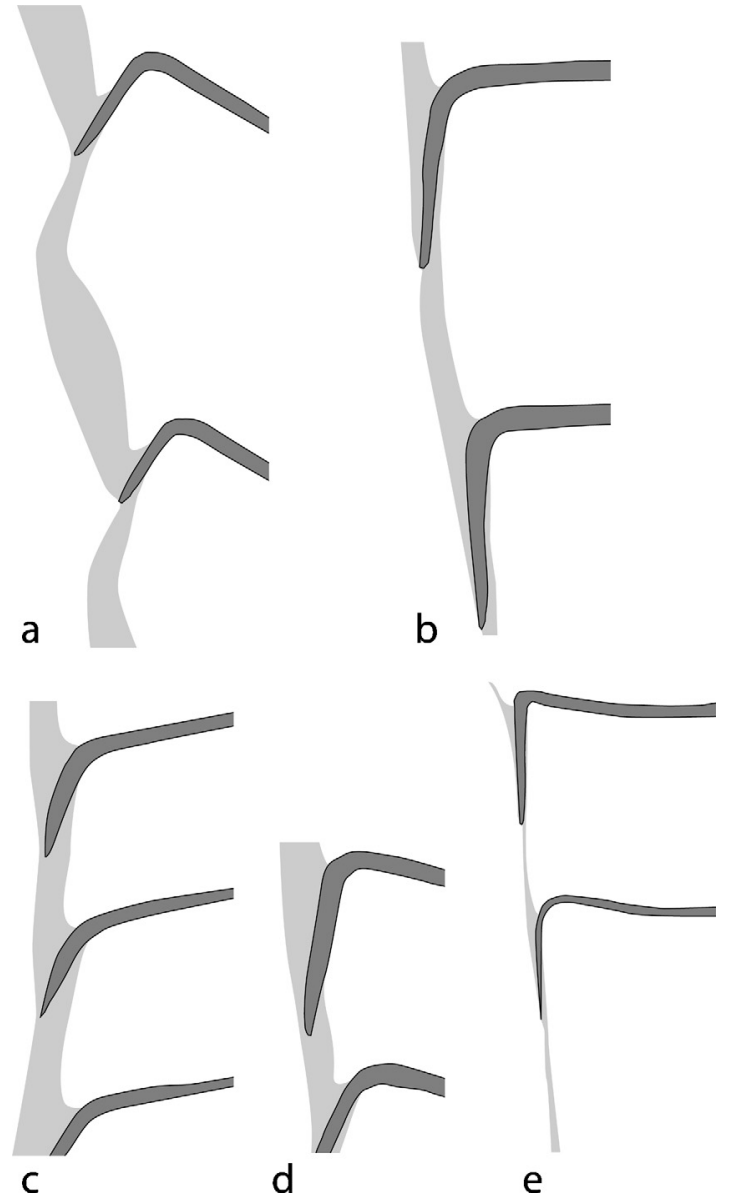

Figure 12. Camera lucida drawings of details of siphuncle and septal necks of cephalopods from the Rochdale Formation (Stairsian) of New York. (a) Bassleroceras vassarina (Dwight, 1884), same specimen as in Figure 13d. (b) Paraendoceras wappingerense (Ulrich et al. 1944), same specimen as in Figure 13f. (c) Exoclitendoceras rochdalense gen. et sp. nov., same specimen as in Figure 13j. (d) Cotteroceras sp., same specimen as in Figure 13i. (e) Clitendoceras saylesi Ulrich \& Foerste, 1935, same specimen as in Figure 13k. (Not to scale.)

1952 Clitendoceras saylesi Ulrich \& Foerste; Flower, p. 508.

1955 Clitendoceras saylesi Ulrich \& Foerste; Flower, p. 365 .

1984 Clitendoceras saylesi Ulrich \& Foerste; Dzik, p. 35, fig. 7.11.

Diagnosis. Clitendoceras species with conch with apical angle approximately $7^{\circ}$. Conch cross-section slightly depressed with prosiphuncular side slightly flattened. Conch slightly curved with nearly marginal siphuncle on concave side of conch. Septa oblique, diverge with angle of $80^{\circ}$ from growth axis, slope adorally on antisiphuncular side. Sutures nearly straight. 8-12 camera occur along a length comparable to conch cross-section. Siphuncle diameter 0.26 times conch cross-section. Siphuncle slightly depressed in cross-section. Siphuncular segments slightly concave (from Ulrich \& Foerste, 1935, p. 268).

Comparison. Clitendoceras montrealense (Billings, 1859) differs from $C$. saylesi in having a smaller siphuncle and a 

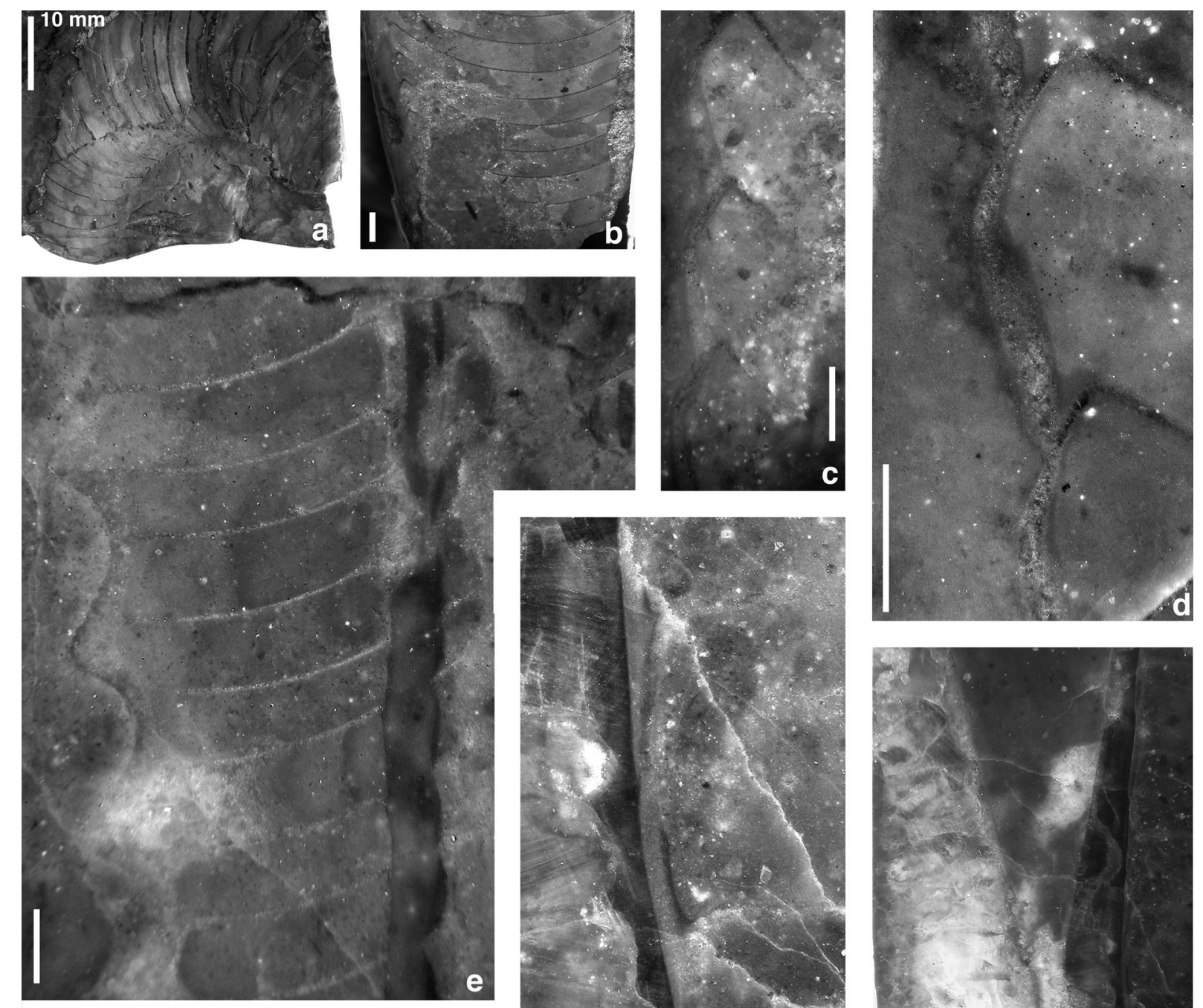

e
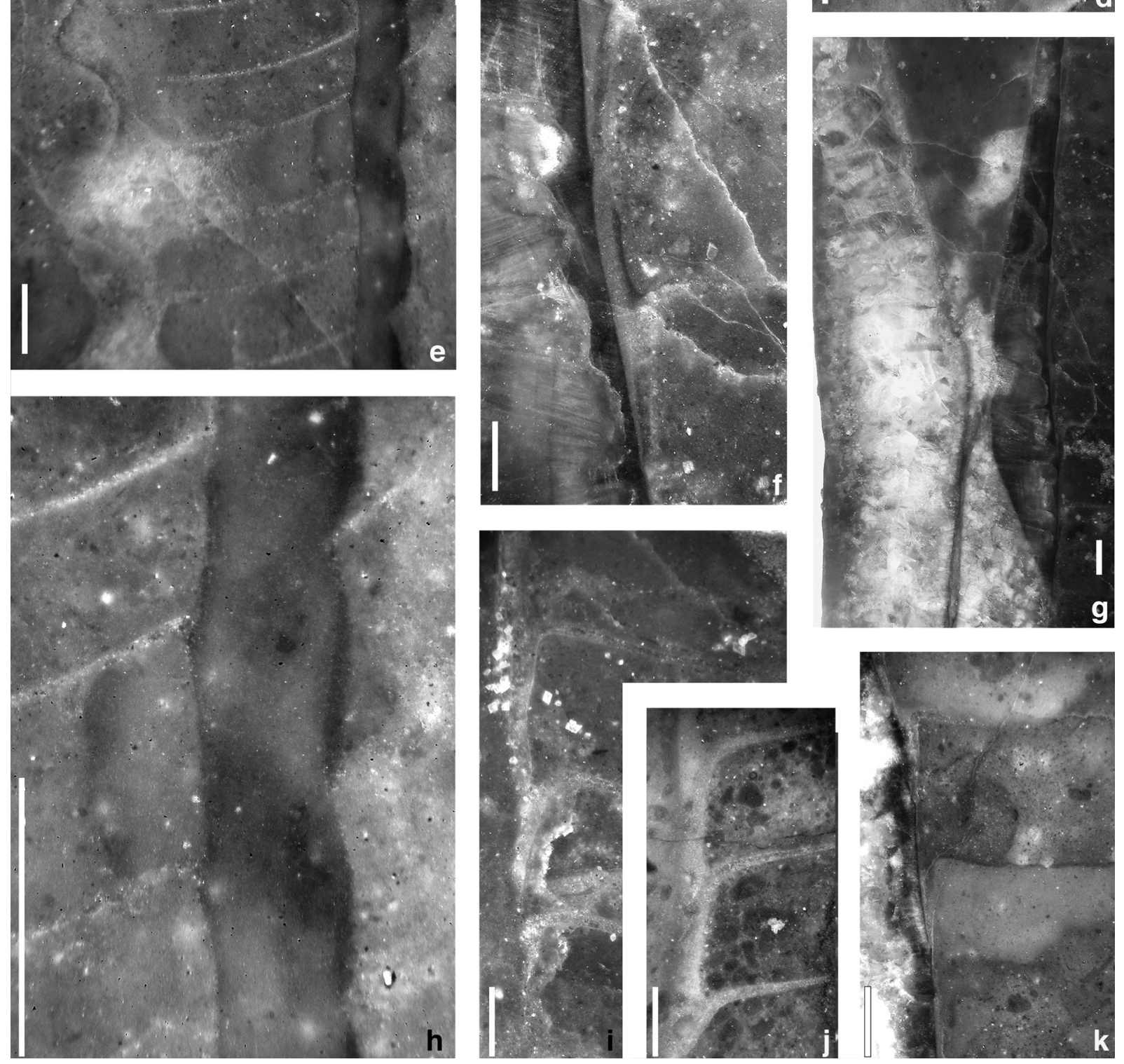

Figure 13. For legend see facing page. 
larger angle of expansion. The siphuncle of $C$. mesleri Ulrich et al. 1944 is larger.

Description. NYSM 17493 (Fig. 14f, g) is a $98 \mathrm{~mm}$ long fragment of one chamber of the phragmocone and the body chamber. At rear of body chamber, conch width is $35 \mathrm{~mm}$ and height is $34 \mathrm{~mm}$. At distance of $50 \mathrm{~mm}$ from body chamber, conch height is $37 \mathrm{~mm}$ and width is $43 \mathrm{~mm}$. Adoral part of body chamber is distinctly depressed, at rear of body chamber conch cross-section nearly circular. Fragment slightly curved with nearly marginal siphuncle on concave side of conch. Body chamber slightly irregularly undulated. Undulations oblique, slope adorally on prosiphuncular side. Specimen strongly dolomitized with exact position of connecting ring and shape of sutures not visible.

NYSM 17494 (Fig. 14j, k; compare also Fig. 13k) is a fragment $37 \mathrm{~mm}$ in length, $24 \mathrm{~mm}$ apical conch height, $26 \mathrm{~mm}$ conch width and $7.8^{\circ}$ angle of expansion. It has well-preserved details of the septal necks and siphuncle. Siphuncle marginal with diameter of $6.5 \mathrm{~mm}$ at apical end of specimen (0.27 times conch cross-section). Septal necks subhemichoanitic to hemichoanitic; septal necks $0.88 \mathrm{~mm}$ long where interseptal distances are $1.25 \mathrm{~mm}$ and $1.4 \mathrm{~mm}$. Septal necks make sharp right angle with septum. Siphuncular segments slightly concave. Connecting ring thin, slightly thickened at segments in contact with septal neck. Endocones are stronger and more elongate on side of siphuncle that faces conch margin. Central canal eccentric, shifted toward centre of conch.

Discussion. Several species of Clitendoceras were erected solely on the basis of characters of the siphuncle. These species are known exclusively from isolated weathered spiculae. In contrast, the shapes of isolated spiculae of C. saylesi and C. montrealense are not known. Only the direct comparison either of complete shells or isolated spiculae can reveal possible synonymies between these species.

Clitendoceras saylesi was thought to have been collected from the Fort Cassin Formation near Whitehall, Washington County, New York, by Ulrich \& Foerste (1935) and Ulrich et al. (1944). However, Flower (1952, p. 508) stated, 'Clitendoceras saylesi Ulrich and Foerste is an endogastric endoceroid, which occurs not in the late Canadian Fort Cassin formation, as stated, but in the underlying beds of middle Canadian age, associated with a fauna characterized by Lecanospira and Hystricus conicus (Billings)...'. This statement means that $C$. saylesi is exclusively known from the Rochdale Formation. Because Flower's statements are not yet tested, the stratigraphic range of $C$. saylesi can be determined only with a detailed revision of the Fort Cassin Formation's cephalopod fauna.
Material examined. Three unnumbered specimens from NYSM locality 5928 (Comstock section); four specimens, NYSM 17493-17496, and nineteen unnumbered specimens in the NYSM Paleontology Collection from NYSM locality 5897 (Smith Basin section), Washington County, New York, from upper part of Rochdale Formation; all collected by R. H. Flower.

Occurrence. Upper part of Rochdale Formation (Stairsian)?Fort Cassin Formation, Tulean-Blackhillsian, Floian, Early Ordovician, Washington County, southern Lake Champlain lowlands, New York.

\section{Genus Cotteroceras Ulrich \& Foerste, 1935}

Type species. Cotteroceras compressum Ulrich \& Foerste, 1935, from the Cotter Formation (Tulean-Blackhillsian, Floian), Chadwick, Christian County, Missouri.

Diagnosis. Proterocameroceratids known from slender orthoconic conchs with compressed cross-section. Siphuncle marginal. Sutures straight and directly transverse, slope slightly adorally on antisiphuncular side. Siphuncle relatively large and in contact with shell wall. Endocones relatively short (from Ulrich \& Foerste, 1935, p. 269).

Comparison. Cotteroceras is unique within the Proterocameroceratidae in having a combination of a straight conch and a compressed cross-section.

Occurrence. Stairsian-Blackhillsian (late TremadocianArenigian); Laurentia, China and Siberia.

Cotteroceras sp.

Figures 12d, 13i, 14i, n, o

Description. Two short fragments of straight conchs with compressed cross-section are known from the Rochdale Formation. Specimen NYSM 17498 has a length of $26 \mathrm{~mm}$, a conch height at the apical end of approximately $24 \mathrm{~mm}$, and a $23 \mathrm{~mm}$ conch width. Conch surface smooth. Interseptal distance about 1.6-2.0 mm. Sutures straight.

Specimen NYSM 17497 (Figs 13i, 14i, n, o) is an $11 \mathrm{~mm}$ long fragment of five chambers of a phragmocone. Conch surface smooth. Conch height $33 \mathrm{~mm}$, width about $30 \mathrm{~mm}$. Septa very slightly oblique, slope adorally on antisiphuncular side. Siphuncle marginal with diameter of $6.7 \mathrm{~mm}$. Septal necks subholochoanitic, with length approximately 0.8 times chamber height, and slightly bent. Septal necks not at right angles to septa but slightly loxochoanitic. Siphuncular segments slightly concave.

Material examined. One specimen; NYSM 17497 from NYSM locality 5904; NYSM 17498 from NYSM locality

Figure 13. Median sections of cephalopods of the Rochdale Formation (Stairsian). Scale bar $1 \mathrm{~mm}$, except at (a). (a) Campbelloceras sp. (NYSM 17518), collected by W. B. Dwight from Rochdale, polished natural section, scale bar $10 \mathrm{~mm}$. (b-d) Bassleroceras vassarina (Dwight, 1884); (b, c) specimen NYSM 10367, collected by W. B. Dwight from Rochdale; (b) note thin marginal siphuncle at the lower left corner of figure; (c) detail showing the thick connecting ring and the loxochoanitc septal necks; (d) specimen NYSM 17480, collected by W. B. Dwight from Rochdale, detail of septal neck and connecting ring. (e) Vassaroceras henrietta (Dwight, 1884) (NYSM 17485) from NYSM locality 5897. (f, g) Paraendoceras wappingerense (Ulich et al. 1944) (NYSM 17502) from NYSM locality 5897; (f) detail showing hemichoanitic septal necks and thick connecting ring; (g) detail of the siphuncle, showing endocameral deposits with central canal and connecting ring. (h) Vassaroceras henrietta (Dwight, 1884) detail of (e). (i) Cotteroceras sp. (NYSM 17497), from NYSM locality 5897, three septa, septal necks and thick connecting ring. (j) Exoclitendoceras rochdalense gen. et sp. nov. (NYSM 17501), from NYSM locality 5897, three septa, septal necks and thick connecting ring. (k) Clitendoceras saylesi Ulrich \& Foerste, 1935, specimen NYSM 17495 from NYSM locality 5897 two septa, septal necks, and thin connecting ring. 

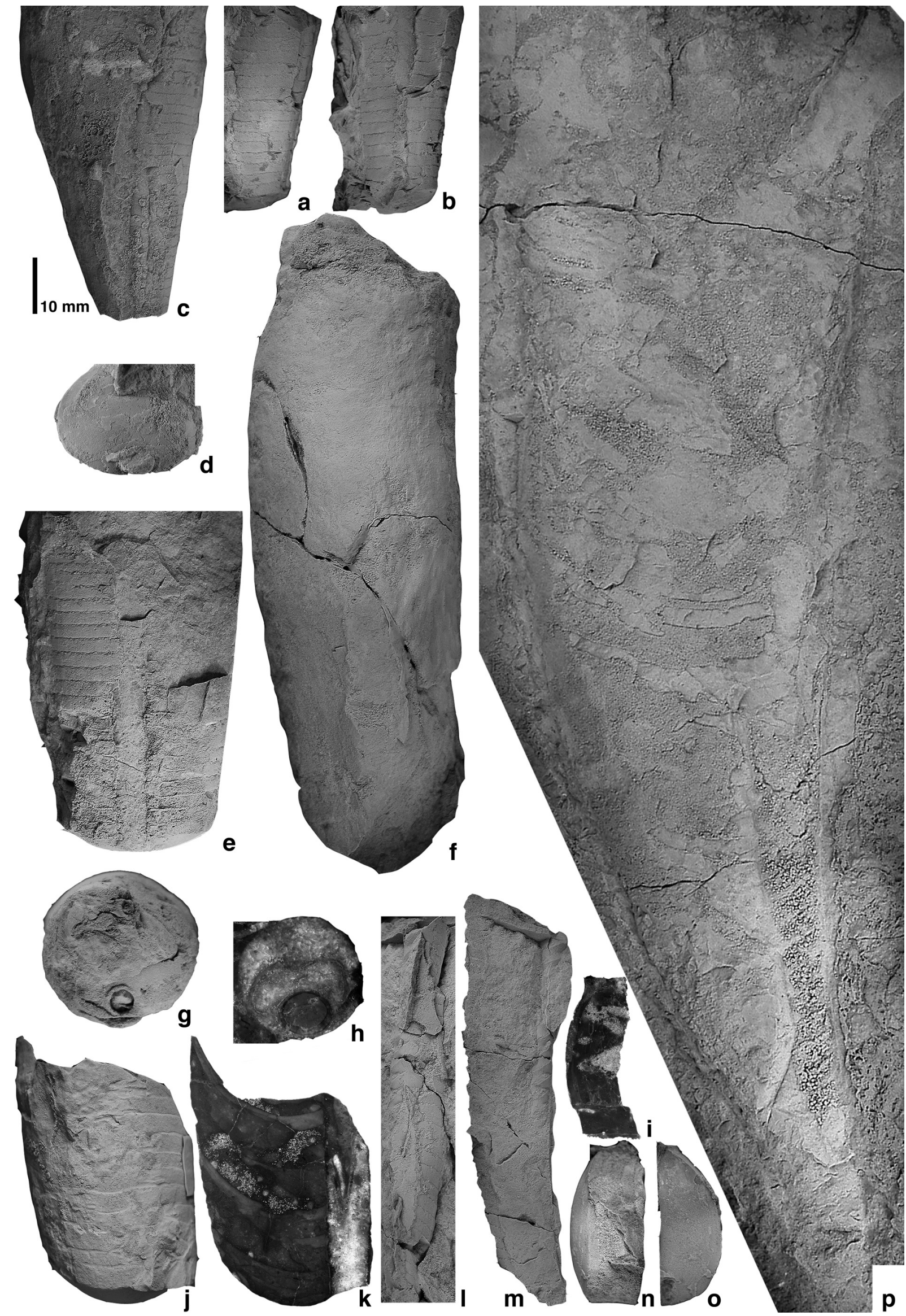

Figure 14. For legend see facing page. 
5916, Washington County, New York; collected by R. H. Flower.

Discussion. The shape of the septal necks reveals that these specimens are referable to the Proterocameroceratidae. The compressed cross-section is diagnostic of Cotteroceras. However, the fragmentary character of the specimens precludes a specific determination.

Occurrence. Upper part of Rochdale Formation, Stairsian, middle Early Ordovician, Washington County, New York.

\section{Genus Exoclitendoceras gen. nov.}

Type species. Exoclitendoceras rochdalense gen. et sp. nov., from the upper part of the Rochdale Formation, Stairsian, middle Early Ordovician, Washington County, New York.

Diagnosis. Proterocameroceratids known from longicones with very slightly curved shells and depressed cross-section. Conch surface smooth or slightly irregularly undulated. Siphuncle marginal on convex side of conch. Septa slightly oblique, slope adorally on antisiphuncular side; about 15 septa occur along a length comparable to conch height. Sutures nearly straight. Siphuncular diameter comparatively small, about 0.25-0.28 times conch height. Siphuncular segments concave; siphuncle circular in cross-section. Septal necks hemichoanitic. At apical portion of phragmocone siphuncle with endocones.

Etymology. Exoclitendoceras (L.); the name evokes a general similarity with Clitendoceras. In contrast to Clitendoceras, the siphuncle in Exoclitendoceras gen. nov. is on the concave side of the conch and the shell is curved exogastrically.

Discussion. Illustrations of the plesiotypes of Protocameroceras brainerdi (Whitfield, 1886) (Ulrich et al. 1944, pl. 30, fig. 3, pl. 31, fig. 3) show slightly oblique sutures that slope adorally on the prosiphuncular side. In addition, the specimens illustrated by Ulrich et al. (1944) are slightly curved, and have the marginal siphuncle on the convex side of the conch. However, Protocameroceras Ruedemann, 1905, is clearly less curved than Exoclitendoceras gen. nov., and the septa of Protocameroceras slope in the opposite direction. The septal necks of Exoclitendoceras gen. nov. are longer than those of Proterocameroceras, and distinctly inclined long loxochoanitic septal necks are present in the latter genus.

Comparison. Exoclitendoceras gen. nov. differs from Proterocameroceras in having a curved conch and oblique septa that slope toward the aperture on the antisiphuncular side. Clitendoceras differs in having the siphuncle on the concave side of the conch, and in lacking the gentle undulation of the conch surface.
Occurrence. Upper Rochdale Formation, Stairsian, middle Early Ordovician, Washington County, New York.

\section{Exoclitendoceras rochdalense gen. et sp. nov.}

Figures 12c, 13j, 15a, b, g

Holotype. NYSM 17499 from NYSM locality 5897 (Smith Basin section), upper part of the Rochdale Formation, Washington County, New York; collected by R. H. Flower (Fig. 15a, b, g).

Paratypes. Two specimens (NYSM 17500 and 17501) from NYSM locality 5897 (Smith Basin section), upper Rochdale Formation, Washington County, New York; collected by R. H. Flower.

Diagnosis. Same as for the genus, by monotypy.

Etymology. rochdalense (L.); the species was first recognized in the Rochdale Formation of Washington County, New York.

Description. Holotype (NYSM 17499) (Fig. 15a, b, g) is fragment of the phragmocone and the complete body chamber with total length of $128 \mathrm{~mm}$, width $41-55 \mathrm{~mm}$, conch height at adapical end $35 \mathrm{~mm}$ (conch width/height ratio 1.17). Angle of expansion of conch width a constant $6^{\circ}$. Conch slightly curved with siphuncle marginal on convex side of conch. Shell surface weakly undulatory with irregular distance between undulations. Body chamber $38 \mathrm{~mm}$ long, with $44 \mathrm{~mm}$ conch width at last septum. Septa slightly oblique, slope adorally on antisiphuncular side, distance between septa $1.8-3.0 \mathrm{~mm}$. Sutures nearly straight. Siphuncle marginal, with $9.2 \mathrm{~mm}$ circular cross-section at adapical end of specimen. Siphuncle completely filled with endocones at adapical end of specimen.

Specimen NYSM 17500 is a fragment of the phragmocone with a length of $113 \mathrm{~mm}, 20 \mathrm{~mm}$ apical conch width and $17 \mathrm{~mm}$ conch height (conch width/height ratio of 1.18). Conch distinctively curved. Angle of expansion of conch width is $6^{\circ}$. Conch surface smooth or only very faintly undulated. Septa nearly transverse; septal distance about $2.7 \mathrm{~mm}$ at adapical part of specimen. Sutures straight. Siphuncle marginal on convex side of conch, siphuncle diameter 0.27 times conch height. Siphuncle completely filled with endosiphuncular deposits at adapical end of specimen.

NYSM 17501 (Fig. 13j) has a siphuncular diameter of $7.7 \mathrm{~mm}$, interseptal distance approximately $2.0 \mathrm{~mm}$, and length of septal necks about $1.0 \mathrm{~mm}$. Straight, hemichoanitic septal necks not normal to septa, but slope at about $20^{\circ}$ towards the axis of the siphuncle. Siphuncular segments slightly concave. Connecting ring about $0.2 \mathrm{~mm}$ thick, with minimum thickness at midlength between septa.

Figure 14. Endocerida of the Rochdale Formation (Stairsian). Scale bar $10 \mathrm{~mm}$. (a-c) Paraendoceras wappingerense (Ulrich et al. 1944); (a, b) specimen NYSM 17508, from NYSM locality 5897 in (a) lateral and (b) prosiphuncular view; (c) specimen NYSM 17512, from NYSM locality 5904 in prosiphuncular view. (d, e) Paraendoceras depressum sp. nov., holotype (NYSM 17513) from NYSM locality 5897 in (d) adapical and (e) prosiphuncular view. (f, g) Clitendoceras saylesi Ulrich \& Foerste, 1935, specimen NYSM 17493 from NYSM locality 5897 in (f) antisiphuncular and (g) adapical view. (h) Paraendoceras wappingerense (Ulrich et al. 1944) holotype (NYSM 10371) collected by W. B. Dwight from Rochdale and figured by Ulrich et al. (1944, pl. 53, figs 3, 4), adapical view. (i, n, o) Cotteroceras sp. (NYSM 17497) from NYSM locality 5897; in (i) median section and (n) lateral and (o) adapical views. (j, k) Clitendoceras saylesi Ulrich \& Foerste, 1935, specimen NYSM 17494 from NYSM locality 5897 in (j) lateral view and (k) median section. (1, m) Mcqueenoceras aff. jeffersonense Ulrich \& Foerste, 1935, (NYSM 17491) from NYSM locality 5897 in (l) prosiphuncular and (m) lateral view. (p) Mccluskiceras comstockense gen. et sp. nov., holotype (NYSM 17492) from NYSM locality 5897 in lateral view. 


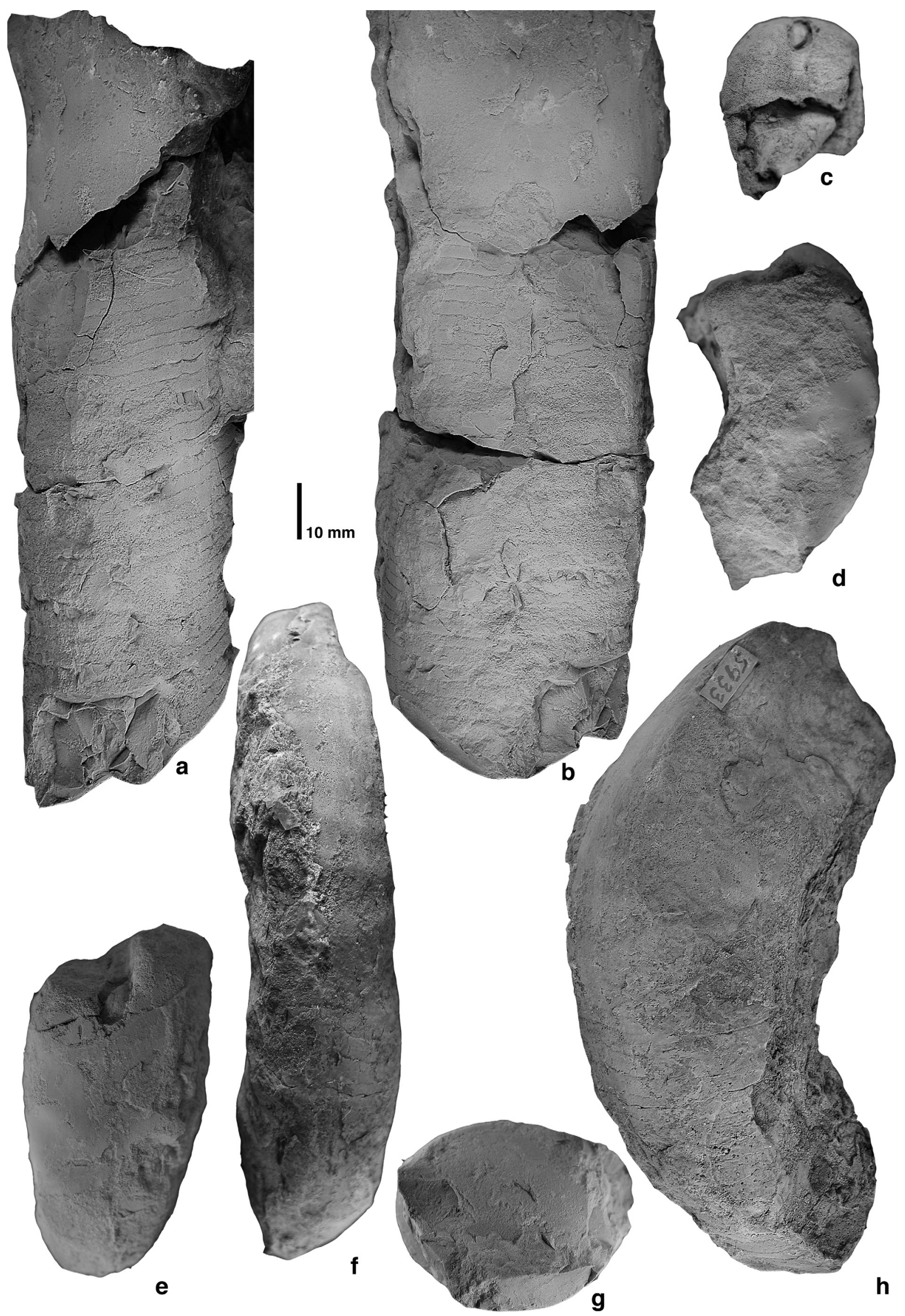

Figure 15. For legend see facing page. 
Occurrence. Upper Rochdale Formation, Stairsian, middle Early Ordovician of Washington County, southern Lake Champlain lowlands, New York.

Genus Mcqueenoceras Ulrich \& Foerste, 1935, emend.

Type species. Mcqueenoceras jeffersonense Ulrich \& Foerste, 1935, from the Jefferson City Formation, TuleanBlackhillsian, Floian, upper Early Ordovician, south of Mansfield, southeast Missouri.

Emended diagnosis. Compressed comparatively slender cyrtocones. Prosiphuncular conch side is straight or slightly concave in earlier growth stages, antisiphuncular side convex. Septa oblique, slope adorally on antisiphuncular side. Sutures form distinct lobes on prosiphuncular side. Siphuncle marginal or very close to conch margin. Siphuncle is flattened on side adjacent to conch. Proximal endocones extended forward on side facing conch. Endosiphuncular tube is strongly eccentric, shifted toward the conch centre (compiled from Ulrich \& Foerste, 1935, p. 279; Flower, 1956, p. 92; Teichert, 1964, p. K166).

Discussion. The original diagnosis (Ulrich \& Foerste, 1935) describes Mcqueenoceras as having a relatively short and rapidly enlarging conch, but the holotype of $M$. jeffersonense has an angle of expansion of about $10^{\circ}$ (Ulrich \& Foerste, 1935, p. 279). Compared with endoceridans of this time, this is rather slender, and the diagnosis is emended accordingly. Mcqueenoceras was assigned to the Endoceratidae by Ulrich et al. (1944) and to the Proterocameroceratidae by Flower (1955). However, judging from the original illustrations, this genus is similar to Cassinoceras and Mccluskiceras gen. nov. in its compressed cyrtoconic conch and the pattern of transverse annulation of the spiculum. Several proterocamerocerids have a compressed conch (e.g. Cotteroceras Ulrich \& Foerste, 1935, and Paraendoceras Ulrich \& Foerste in Foerste, 1936 in early growth stages). Other proterocameroceratids have a spiculum with annuli that slope adorally on the side that faces the conch wall (e.g. Clitendoceras Ulrich \& Foerste, 1935; Cotteroceras; Proterocameroceras Ruedemann, 1905). These characters are typical for piloceratids. Thus, there is a large morphological spectrum with transitions between a typical compressed, cyrtoconic, breviconic Piloceratidae form (e.g. Piloceras) and the slightly depressed, straight longiconic Proterocameroceratidae form (e.g. Proterocameroceras).

Mcqueenoceras has a compressed, cyrtoconic shell with a marginal siphuncle on the concave side of the conch, and a spiculum with annuli that slope adorally toward the conch wall. These three characters are typical for piloceratids. However, Mcqueenoceras from the Rochdale Formation exhibits hemichoanitic septal necks, which are diagnostic for the Proterocameroceridae. Earlier descriptions of the genus fail to provide information on the septal neck shape and length. However, Flower (1956) and Teichert (1964) assigned the genus to the Proterocameroceratidae, thus implying nonholochoanitic septal necks. Therefore, the genus is best assigned to the Proterocameroceridae. A confident family assignment of Mcqueenoceras will be possible only after revision and emendation of the Proterocameroceratidae, Piloceratidae and the type material.

Comparison. Mcqueenoceras differs from Cassinoceras Ulrich \& Foerste, 1935 and Mccluskiceras gen. nov. in having a clearly more slender conch. Clitendoceras Ulrich \& Foerste, 1935 differs in having a depressed conch cross-section, a lower angle of expansion and straight sutures.

Occurrence. Stairsian-Blackhillsian, upper Early Ordovician; Laurentia, Siberian Platform.

Mcqueenoceras aff. jeffersonense Ulrich \& Foerste, 1935 Figure 141, m

1935 Mcqueenoceras jeffersonense Ulrich \& Foerste, p. 279 , pl. 38 , fig. 2 .

1943 Mcqueenoceras jeffersonense Ulrich \& Foerste; Ulrich, Foerste \& Miller, p. 143, pl. 68, figs 3-12.

1948 Mcqueenoceras jeffersonense Ulrich \& Foerste; Cloud \& Barnes, pl. 42, fig. 34.

1956 Mcqueenoceras jeffersonense Ulrich \& Foerste; Flower, p. 93.

1961 Mcqueenoceras jeffersonense Ulrich \& Foerste; Unklesbay, p. 374, pl. 51, fig. 2.

Diagnosis. Mcqueenoceras species with conch angle of expansion of about $10^{\circ}$. Width/height ratio approximately 0.8 in elliptically compressed conch. Prosiphuncular conch side slightly concave, antisiphuncular side convex. Septa oblique, slope adorally on antisiphuncular side. Siphuncle marginal or very close to conch wall, with diameter approximately 0.3 times conch cross-section. Apical part of siphuncle with endosiphuncular cones. Spiculum has about six annulations along a length comparable to cross-section of siphuncle.

Description. Specimen $69 \mathrm{~mm}$ long, apical conch height approximately $9.0 \mathrm{~mm}$, adoral conch height approximately $25 \mathrm{~mm}$ (angle of expansion $14^{\circ}$ ). Conch slightly cyrtocone, elliptically compressed with width/height ratio approximately 0.8 . Conch surface smooth.

Siphuncle marginal on concave side of conch, with $6.5 \mathrm{~mm}$ diameter at adoral end of specimen ( 0.26 times conch cross-section). Siphuncle flattened on side that faces conch wall. Spiculum has oblique annuli and sharp ridges; ridges slope adorally toward conch wall and form sharp angulate saddle on side that faces conch wall.

Interseptal distance at adoral end approximately $2.4 \mathrm{~mm}$, at adapical end $1.4 \mathrm{~mm}(6-10$ septa per corresponding conch height). Septa oblique, slope adorally on antisiphuncular side.

Discussion. This species was previously reported only from the Jefferson City Formation of southern Missouri, which is significantly younger in age (approximately equivalent to the Fort Cassin Formation on the NE Laurentian platform). The single specimen from the Rochdale Formation differs from the Jefferson City specimens described by Ulrich \& Foerste (1935) and Ulrich, Foerste \& Miller (1943) in having a higher angle of expansion. However, because the variability of the Jefferson City species is not known and the Rochdale specimen is the only known specimen

Figure 15. Endocerida and Tarphycerida of the Rochdale Formation (Stairsian). Scale bar $10 \mathrm{~mm}$. (a, b, g). Exoclitendoceras rochdalense sp. nov., holotype (NYSM 17499) from NYSM locality 5897 in (a) lateral, (b) prosiphuncular view, and (g) adapical view. (c-e) Campbelloceras sp. (NYSM 17517) from NYSM locality 5904 in (c) adapical, (d) lateral, and (e) ventral view, note the umbilical zone visible in (c). (f, h) Aphetoceras sp. (NYSM 17515) from NYSM locality 5933 in (f) ventral and (h) lateral view. 
from New York, insufficient data are available to evaluate if the Rochdale specimen represents a new species or an intraspecific variant of $M$. jeffersonense. The Rochdale specimen is assigned tentatively to $M$. jeffersonense until more material is available.

Material examined. One specimen, NYSM 17491, from NYSM locality 5897; collected by R. H. Flower.

Occurrence. Upper part of Rochdale Formation, Stairsian, middle Early Ordovician, NYSM locality 5897 (Smith Basin section), Washington County, southern Lake Champlain lowlands, New York.

\section{Genus Mccluskiceras gen. nov.}

Type species. Mccluskiceras comstockense gen. et sp. nov., from the upper Rochdale Formation, Stairsian, middle Early Ordovician, Washington County, New York.

Diagnosis. Large, cyrtoconic endoceridans with oval, compressed cross-section. Prosiphuncular side of conch slightly concave to almost straight, antisiphuncular side conspicuously convex. Angle of expansion in apical $120 \mathrm{~mm}$ approximately $22^{\circ}$, in later growth stages $6^{\circ}$. Sutures with shallow lateral lobes. Septa slope adorally on prosiphuncular side. Septal necks short. Siphuncle distinctly compressed laterally, with diameter approximately 0.3 times conch crosssection, filled with massive endosiphuncular cones in apical portion of conch.

Etymology. Named for Dr Loretta McCluskey, owner of the property in Rochdale, New York, from which section Ro-R in the upper Rochdale Formation was described.

Comparison. Mccluskiceras gen. nov. differs from Cassinoceras Ulrich \& Foerste, 1935 in having a low angle of expansion and a sharp decrease in the angle of expansion during growth and in having short septal necks. The angle of expansion of Mccluskiceras is larger than that of Mcqueenoceras in early growth stages and smaller in latest growth stages.

Occurrence. Upper part of the Rochdale Formation, Stairsian, middle Early Ordovician of Washington County, southern Lake Champlain area, New York.

\section{Mccluskiceras comstockense gen. et sp. nov. Figure $14 \mathrm{p}$}

Holotype. NYSM 17492, from NYSM locality 5928 (Comstock section), upper part of Rochdale Formation, Stairsian, Washington County, NY; collected by R. H. Flower.

Diagnosis. Same as for the genus.

Etymology. comstockense (L.); the species was first recognized east of Comstock, Washington County, New York.

Description. Holotype is fragment of apical part of phragmocone, with total length of about $195 \mathrm{~mm}$ and maximum conch height of $67 \mathrm{~mm}$. Conch cross-section elliptically compressed, conch width/height ratio cannot be detected, as largest part of specimen is embedded in rock matrix. Conch surface smooth. Apex rounded with large angle of expansion, conch height $10 \mathrm{~mm}$ from apex is $13 \mathrm{~mm}, 21 \mathrm{~mm}$ at $20 \mathrm{~mm}$ from apex, and $53 \mathrm{~mm}$ at $120 \mathrm{~mm}$ from apex. Average angle of expansion of conch height is $22^{\circ}$; conch grows only $14 \mathrm{~mm}$ in width until length of $195 \mathrm{~mm}$ is reached, with angle of expansion of conch width of $6^{\circ}$. Growth axis slightly curved. Prosiphuncular conch margin slightly concave, antisiphuncular conch margin distinctively convex. Siphuncle marginal, with diameter approximately $6.5 \mathrm{~mm}$ at $10 \mathrm{~mm}$ from apex. $75 \mathrm{~mm}$ from apex, diameter of siphuncle is $13.5 \mathrm{~mm}$ and conch height is $47 \mathrm{~mm}(0.29$ times conch cross-section). Apical $83 \mathrm{~mm}$ of siphuncle filled with endosiphuncular deposits. Siphuncular segments slightly concave. Septal necks short. Septa slightly oblique, slope adorally on antisiphuncular side. Interseptal distance approximately $3.5 \mathrm{~mm}$ beginning $15 \mathrm{~mm}$ from apex; this spacing continues through entire specimen.

Occurrence. Upper part of Rochdale Formation, Stairsian, middle Early Ordovician of Washington County, southern Lake Champlain lowlands, New York.

\section{Genus Paraendoceras Ulrich \& Foerste in Foerste,} 1936, emend.

Type species. Saffordoceras jeffersonense Ulrich \& Foerste, 1935, from the Roubidoux Formation, Stairsian, southwest of Jefferson City, Jefferson County, Tennessee.

Emended diagnosis. Protocameroceratid genus with orthoconic conchs with slightly compressed-depressed crosssection and comparatively high angle of expansion of more than $10^{\circ}$. Sutures straight and directly transverse. Siphuncle marginal, comparatively small with diameter about $0.3-0.4$ times conch cross-section. Siphuncular segments slightly concave. Connecting ring thin. Septal necks hemichoanitic. Apically long endocones occur.

Discussion. The emendation provides more specific information on the angle of expansion and the diameter of the siphuncle. In the earlier diagnoses by Ulrich \& Foerste (in Foerste, 1936), Ulrich et al. (1944) and Teichert (1964), the angle of expansion and the siphuncular diameter were vaguely described (e.g. Teichert, 1964, p. K170, 'fairly rapidly enlarging conchs').

We have broadened the diagnosis to include forms with slightly compressed and depressed cross-section. The Rochdale Formation contains cephalopods that resemble Paraendoceras jeffersonense, but have a variable crosssection. In addition, the material from the Rochdale Formation allowed an investigation of the details of the siphuncle and septal necks. New information on the shape of the connecting ring and septal necks is included in the emended diagnosis.

Comparison. Paraendoceras differs from Cotteroceras in having a larger angle of expansion, a depressed conch crosssection in adult growth stages, and a larger siphuncle.

Occurrence. Stairsian-Blackhillsian (late TremadocianArenigian); Laurentia.

Paraendoceras wappingerense (Ulrich et al. 1944) emend. Figures 12b, 13f, g, 14a-c, h

1944 Endoceras? wappingerense Ulrich et al., p. 102, pl. 53, figs $1-5$.

1944 Endoceras? warthini Ulrich et al., p. 103, pl. 49, figs $1-2$.

1955 Proendoceras wappingerense(Ulrich et al.); Flower, p. 344.

1955 Proendoceras warthini (Ulrich et al.); Flower, p. 345.

Emended diagnosis. Paraendoceras with conchs with apical angle approximately $16^{\circ}$. Conch cross-section slightly 
compressed in juvenile growth stages, depressed in later growth stages. Cross-section nearly circular in fragments with 16-19 mm conch width. Septa transverse and with straight sutures. Nine camera occur in a length comparable to conch cross-section. Siphuncle marginal, diameter 0.39 times conch cross-section, slightly depressed in cross-section. Siphuncular segments slightly concave. Connecting ring thin. Septal necks hemichoanitic. Endocones in apical part of siphuncle with central canal.

Description. The holotype (Fig. 14h) was described in detail by Ulrich et al. (1944). Its angle of expansion is $14^{\circ}$, with a conch width/height ratio of 1.11 where conch width is $25.8 \mathrm{~mm}$; the ratio is 1.04 where the conch width is $19.4 \mathrm{~mm}$.

A second specimen (NYSM 17504, collected by W. B. Dwight) is a fragment of the phragmocone with a length of $32 \mathrm{~mm}$, adoral conch diameter of $25 \mathrm{~mm}$, and adapical conch diameter of $16 \mathrm{~mm}$. Conch cross-section nearly circular. Sutures straight, with approximately $1.5 \mathrm{~mm}$ spacing. Siphuncular diameter not determined because of fragmentary character of specimen. Connecting ring thin, with slightly concave tubular segments. Septal necks hemichoanitic.

An additional 29 specimens of Paraendoceras wappingerense collected by R. H. Flower are in the NYSM Paleontology Collection. These specimens are fragmentary, and largely tectonically compressed or depressed. All specimens with a conch cross-section smaller than $15 \mathrm{~mm}$ are compressed. Their angle of expansion varies between 14 and $20^{\circ}\left(16^{\circ}\right.$ average, $\mathrm{n}=7$ ), and their septa are invariably transverse and with straight sutures. Additional features include: siphuncle marginal, with slightly concave segments; connecting ring thin, thickest at midlength between chambers; septal necks hemichoanitic; endosiphuncular deposits form cones with central canal.

Specimen NYSM 17502 (Fig. 13f, g) displays characters of the siphuncle and septal necks in a medial section: interseptal distance $2.25 \mathrm{~mm}$ at conch height of $24 \mathrm{~mm}$; septal thickness $0.1 \mathrm{~mm}$; septal necks orthochoanitic with $1.25 \mathrm{~mm}$ length, span about half the length of the siphuncular segment; siphuncular segments slightly concave; connecting rings thickest at contact with adapical septum, with thickness of $0.3 \mathrm{~mm}$ at midlength and $0.15 \mathrm{~mm}$ between adapical end of septal neck and adapical septum; siphuncular diameter $7.3 \mathrm{~mm}$; endosiphuncular cones thicker on side facing conch wall; central canal $0.3 \mathrm{~mm}$ thick.

Discussion. The original diagnosis of Ulrich et al. (1944) is emended to include additional information on the septal neck shape and the ontogenetic variation in conch crosssection. Ulrich et al. (1944) described in detail a few specimens from the original collection of W. B. Dwight. An additional specimen in the NYSM Paleontology Collection was collected by Dwight, but was not described by Ulrich et al. (1944). This specimen (NYSM 17504) shows details of the siphuncle and septal necks.

The more than 30 specimens of Paraendoceras wappingerense in the NYSM Paleontology Collection show a considerable variability in angle of expansion and septal spacing (compare Fig. 14b and c). However, based on the available material, the angle of expansion or septal spacing cannot be used to differentiate Paraendoceras species. Therefore, Endoceras? warthini is regarded as subjective senior synonym of $P$. wappingerense.

Both of the latter forms were assigned to Proendoceras Flower, 1955 by Flower (1955). However, Proendoceras is based on the very incompletely known type species $P$. annuliferum Flower, 1941, which differs in having shorter septal necks and slightly convex siphuncular segments.

Comparison. Paraendoceras wappingerense differs from $P$. jeffersoni in having a cross-section that changes from compressed to depressed during ontogeny. Paraendoceras depressum differs in having a strongly depressed conch crosssection and slightly oblique septa. However, because the intraspecific variability of $P$. jeffersoni is not known and the possibility remains that $P$. depressum is a tectonically deformed $P$. wappingerense, the species of the highly variable Paraendoceras may reflect a single species only.

Material examined. Holotype NYSM 10371 and hypotype NYSM 17504, originally labelled ' 301 . Endoceras Cameroceras? wappinger.' by W. B. Dwight from the Rochdale Formation at Rochdale, Dutchess County. The remaining specimens come from the upper Rochdale Formation in Washington County. One specimen NYSM 17505 from NYSM locality 5916; seven specimens, NYSM 17502, 17503, 17506-17511, from NYSM locality 5897 (Smith Basin section), one specimen NYSM 17512 from NYSM locality 5904. In addition, 18 unnumbered specimens from NYSM locality 5897 (Smith Basin section), and two unnumbered specimens from NYSM locality 5904.

Occurrence. Upper Rochdale Formation, Stairsian, middle Early Ordovician at Rochdale, Dutchess County, and from Washington County, southern Lake Champlain lowlands, New York.

Paraendoceras depressum sp. nov. Figure 14d, e

Holotype. NYSM 17513 from NYSM locality 5897 (Smith Basin section), upper Rochdale Formation, Washington County, New York; collected by R. H. Flower (Fig. 14d, e).

Paratype. NYSM 17514 collected by W. B. Dwight from the upper Rochdale Formation at Rochdale, Dutchess County, New York.

Diagnosis. Paraendoceras species with apical angle approximately $11^{\circ}$. Conch cross-section depressed with conch width/height ratio of 0.76 . Septa transverse, slightly oblique, slope adorally on antisiphuncular side, with straight sutures. 8-9 camera occur along a length comparable to conch cross-section. Siphuncle marginal, diameter approximately 0.3 times conch height, slightly depressed in cross-section. Connecting ring thin. Septal necks hemichoanitic.

Etymology. depressum (L.); refers to the depressed conch cross-section of this species.

Description. The holotype (Fig. 14d, e) is a $75 \mathrm{~mm}$ long fragment of a phragmocone with conch width $25 \mathrm{~mm}$, and conch height $19 \mathrm{~mm}$ at apical end. Angle of expansion $11^{\circ}$. Conch cross-section elliptically depressed with conch width/height ratio of 0.76 . Septa slightly oblique, slope adorally on antisiphuncular side. Sutures straight. Interseptal distance $2.3 \mathrm{~mm}$ at adapical end of specimen. Siphuncle marginal, with $5.8 \mathrm{~mm}$ width and $5.5 \mathrm{~mm}$ height at apical end of specimen. Siphuncular segments slightly concave. Thin, conical endosiphuncular deposits at apical end of specimen.

A second specimen, NYSM 17514, is a $40 \mathrm{~mm}$ long, fragmentary phragmocone. Fragment includes only left half of conch. Reconstructed adapical conch width is $16.6 \mathrm{~mm}$, adoral conch width is $25 \mathrm{~mm}$, angle of expansion $12^{\circ}$. Interseptal distance at apical end of specimen is $1.6 \mathrm{~mm}$. 
Siphuncle marginal, with $6.8 \mathrm{~mm}$ diameter at adoral end of specimen. Siphuncular segments concave. Siphuncle filled with endocones.

Comparison. Paraendoceras depressum differs from P. wappingerense in having a depressed cross-section throughout the entire conch and slightly oblique septa. In contrast, $P$. wappingerense has a compressed cross-section in early growth stages. However, $P$. depressum is based on two specimens only and the possibility remains that these are tectonically deformed specimens. Based on the available material, the specimens must be placed in a separate species. Future material will support or disapprove this species.

Occurrence. Upper Rochdale Formation, Stairsian, middle Early Ordovician from Rochdale, Dutchess County, and from Washington County, southern Lake Champlain lowlands, New York.

\section{Order TARPHYCERIDA Flower in Flower \& Kummel, 1950 \\ Family ESTONIOCERATIDAE Hyatt, 1900 Genus Aphetoceras Hyatt, 1894}

Type species. Aphetoceras americanum Hyatt, 1894, St George Group, Early Ordovician, Port au Choix, Newfoundland.

Diagnosis. Estonioceratids with loosely coiled, gradually expanding conch with oval, compressed cross-section, weak ribs commonly occur. Early whorls in contact or nearly so, mature ultimate whorl widely divergent. Sutures nearly straight, with shallow lateral lobes and dorsal and ventral saddles. Siphuncle subventral in all growth stages, diameter 0.1-0.3 times conch height (compiled from Ulrich et al. 1942, p. 17; Furnish \& Glenister, 1964b, p. K358).

Comparison. Aphetoceras differs from Clytoceras Ulrich et al. 1942 in having an openly coiled conch and a lower angle of expansion. Shumardoceras Ulrich \& Foerste, 1935 differs in having a closely coiled conch and a narrowly rounded subangular venter. Campbelloceras Ulrich \& Foerste, 1935 differs in having a tightly coiled conch with distinctively impressed umbilical zone and a circular cross-section.

Occurrence. Stairsian-Blackhillsian (late TremadocianArenigian); Laurentia, East Gondwana (Australia).

\section{Aphetoceras sp. \\ Figure 15f, h}

Description. Two fragments of openly coiled conchs with compressed cross-section are known from the upper Rochdale Formation. Specimen NYSM 17515 (Fig. 15f, h) is a strongly tectonically deformed fragment of part of the body chamber and phragmocone with maximum conch height of $37 \mathrm{~mm}$ and minimum conch height of $32 \mathrm{~mm}$ (angle of expansion about $4^{\circ}$ ). Conch width at apical part of specimen about $25 \mathrm{~mm}$. Fragmentary body chamber $73 \mathrm{~mm}$ long. Adoral part of body chamber has shallow rounded undulations with spacing of approximately $10 \mathrm{~mm}$. Crosssection oval with maximum width on ventral half and broadly rounded venter. Septa directly transverse, with $4.3 \mathrm{~mm}$ interseptal distance at venter at conch height of $36 \mathrm{~mm}$. Sutures form very shallow lateral lobe. Siphuncle close to the venter, but not marginal.

Specimen NYSM 17516 is a weathered section approximately along the median axis of the phragmocone. About one and a half whorls present. Minimum conch height diameter is $9.8 \mathrm{~mm}$, conch height at approximately $290^{\circ}$ in growth direction is $26 \mathrm{~mm}$. Conch cross-section a compressed oval. Conch openly coiled and whorls clearly not in contact. Ventral interseptal distance is $3.7 \mathrm{~mm}$ where conch height is $26 \mathrm{~mm}$. Septa directly transverse. Siphuncle not visible.

Discussion. NYSM 17515 is strongly deformed, and the inner whorls are not preserved. However, the degree of coiling and parts of the conch cross-section are preserved. The specimen must be assigned to Aphetoceras because the conch cross-section is not angular ventrally and the coiling is loose. NYSM 17516 is also assigned to Aphetoceras because it is an openly coiled conch with a comparatively low angle of expansion, and it has a compressed conch cross-section.

Material examined. Specimen NYSM 17515 from NYSM locality 5933, and specimen NYSM 17516 from NYSM locality 5928 (Comstock section), Washington County, New York; collected by R. H. Flower.

Occurrence. Upper Rochdale Formation, Stairsian, middle Early Ordovician, Washington County, New York.

Family TARPHYCERATIDAE Hyatt, 1894

Genus Campbelloceras Ulrich \& Foerste, 1935

Type species. Eurystomites virginianus Hyatt, 1894, from the Cotter Formation, Tulean-Blackhillsian, Floian, from northwest of Lexington, Rockbridge County, Virginia.

Diagnosis. Tarphyceratids with tightly coiled conch with shallow but distinctly impressed umbilical zone and nearly circular or depressed cross-section. Ornamented with faint growth lines that form distinctive, broad rounded ventral sinus. Living chamber about two-fifths of a whorl in length. Siphuncle close to venter in all growth stages. Sutures nearly straight (compiled from Ulrich et al. 1942, p. 43).

Comparison. Campbelloceras differs from Eurystomites Schröder, 1891 in having a nearly circular cross-section, a higher angle of expansion, and a nearly ventrally positioned siphuncle.

Occurrence. Stairsian-Blackhillsian, (late TremadocianArenigian); Laurentia.

\section{Campbelloceras sp.}

Figures 13a, 15c-e

Description. Two fragments of tightly coiled conchs with nearly circular cross-section are known from the Rochdale Formation. NYSM 17517 (Fig. 15c-e) is a partly dolomitized fragment of a phragmocone with a length of approximately $50 \mathrm{~mm}$, adoral conch width of $28 \mathrm{~mm}$, adoral conch height of $29 \mathrm{~mm}$, and adapical conch height of $26 \mathrm{~mm}$. Fragment spans less than one-fourth of a volution. Conch crosssection is subquadratic with siphuncle close to venter. Conch slightly undulated. Undulations shallow, with distance of approximately $10 \mathrm{~mm}$, form distinctive lobe at venter with depth that equals distance between two subsequent undulations (Fig. 15e). A distinctive impressed zone occurs on the concave side of the whorl. The ventral interseptal distance is approximately $3 \mathrm{~mm}$. Sutures directly transverse. Siphuncle diameter $4.8 \mathrm{~mm}$ at adoral end of fragment $(0.17$ times conch height).

NYSM 17518 (Fig. 13a) is a fragment of a phragmocone that spans one-fourth of two volutions. The inner whorl has a conch height of $12 \mathrm{~mm}$, and the outer whorl is approximately $28 \mathrm{~mm}$ high. The conch cross-section is nearly circular, and 
the septa are directly transverse. The ventral distance between septa is approximately $3.0 \mathrm{~mm}$ at a conch width of $25 \mathrm{~mm}$.

Discussion. NYSM 17517 is subquadratic in cross-section and slightly undulated. However, the tightly coiled conch, the general shape of the conch cross-section, the position of the siphuncle, and the straight sutures are all diagnostic characters of Campbelloceras. A specific determination is not possible because of the poor preservation.

The second specimen, NYSM 17518 (Fig. 13a), is in a polished limestone block that exposes a cross-section and a median section of the fragment. The siphuncle is not visible, but it can be concluded that it was close to the venter, because the siphuncle is not visible in the well-exposed dorsal and central portions of the phragmocone. The subcircular crosssection, the position of the siphuncle and the tight coiling of the specimen are diagnostic characters of Campbelloceras.

Material examined. NYSM 17517 from NYSM locality 5904, Washington County, New York; collected by R. H. Flower. NYSM 17518 from Rochdale, Dutchess County, New York; collected and labeled by W. B. Dwight as 'Eurystomites armilla n. sp.'.

Occurrence. Upper part of Rochdale Formation, Stairsian, middle Early Ordovician, Dutchess and Washington counties, New York.

Acknowledgements. BK is grateful for discussions with D. Evans (Peterborough, UK) that helped to develop the ideas presented herein on early endocerid evolution. BK's work was financially supported by DFG fund KR 2095/2 and by the NYSM. We are grateful for the helpful comments of D. Evans and Ian Percival (Sydney, Australia). This paper constitutes a contribution to IGCP 503.

\section{References}

Balashov, Z. G. 1955. Ordovician nautiloids. In Field Atlas of the Ordovician and Silurian fauna of the Siberian Platform (eds Team of Authors), pp. 87-104. St Petersburg: Gostechgeologistat (in Russian).

BAlASHOV, Z. G. 1968. Ordovician Endoceratoidea of the USSR. St Petersburg: Isdatel'stvo Leningradskogo Universiteta, 170 pp. (in Russian).

BASSLER, R. S. 1915. Bibliographic index of American Ordovician and Silurian Fossils. Bulletin of the United States National Museum 92, 1521 pp.

BILlingS, E. 1859. Fossils of the Calciferous Sandrock, including those of a deposit of white limestone at Mingan, supposed to belong to the formation. Canadian Naturalist and Geologist, Proceedings of the Society of Natural History of Montreal 4, 345-67.

BillingS, E. 1865. Palaeozoic fossils. Containing descriptions and figures of new or little known species of organic remains from the Silurian rocks. Geological Survey of Canada, Montreal 1, 169-394.

BRUGIÈRE, J. G. 1789. Histoire naturelle des vers. Vol. 1.1. Encyclopedie methodique 6, 1-757.

CADY, W. M. 1945. Stratigraphy and structure of west-central Vermont. Geological Society of America Bulletin 56, 515-58.

CHAO, A. 1984. Non-parametric estimation of the number of classes in a population. Scandinavian Journal of Statistics 11, 265-70.

Chazdon, R. L., Colwell, R. K., Denslow, J. S. \& GUARIGUATA, M. R. 1998. Statistical methods for estimating species richness of woody regeneration in primary and secondary rain forests of NE Costa Rica. In Forest biodiversity research, monitoring and modeling: Conceptual background and Old World case studies (eds F. Dallmeier \& J. A. Comiskey), pp. 285-309. Paris: Parthenon Publishing, $671 \mathrm{pp}$.

ClARKE, J. M. \& SCHUCHERT, C. 1899. The nomenclature of the New York series of geological formations. Science (new series) 1899, 876-7.

Clarke, K. R. \& WARWICK, R. M. 1998. A taxonomic distinctness index and its statistical properties. Journal of Applied Ecology 35, 523-31.

Clarke, K. R. \& WARWICK, R. M. 1999. The taxonomic distinctness measure of biodiversity: weighting of step lengths between hierarchical levels. Marine Ecology Progress Series 184, 21-9.

Cloud, P. E. \& BARNES, V. 1948. The Ellenburger Group of central Texas. University of Texas Publications 4621, $473 \mathrm{pp}$.

COLWELL, R. K. 2005. EstimateS: Statistical estimation of species richness and shared species from samples. Version 7.5. User's Guide and application published at: http://purl.oclc.org/estimates.

Dwight, W. B. 1879. On some recent explorations in the Wappinger valley limestone of Dutchess Co., N. Y. No. 2. Calciferous as well as Trenton fossils in the Wappinger Limestone at Rochdale and a Trenton locality at Newburgh, N. Y. American Journal of Science, third series 17, 289-92.

DwIGHT, W. B. 1880. Recent explorations in the Wappinger valley limestones and other formations of Dutchess Co., N. Y. No. 2. Calciferous as well as Trenton fossils in the Wappinger Limestone at Rochdale and a Trenton locality at Newburgh, N. Y. American Journal of Science, third series 17 (101), 50-4.

DwIGHT, W. B. 1881. Further discoveries of fossils in the Wappinger Valley or Barnegat limestone. American Journal of Science, third series 21, 78-9.

DwIGHT, W. B. 1884. Recent explorations in the Wappinger valley limestones and other formations of Dutchess Co., N. Y. No. 4. Descriptions of Calciferous (?) fossils. American Journal of Science 27, 249-59.

DwIGHT, W. B. 1889. Recent explorations in the Wappinger valley limestones and other formations of Dutchess Co., N. Y. No. 8. Discovery of Calciferous fossils in the Millerton-Fishkill limestone belt; also in a belt near Rhinebeck. American Journal of Science 38, $150-83$.

DzIK, J. 1984. Phylogeny of the Nautiloidea. Palaeontologia Polonica 45, $203 \mathrm{pp}$.

Evans, D. H. 2005. The Lower and Middle Ordovician cephalopod faunas of England and Wales. Monograph of the Palaeontographical Society 628, $81 \mathrm{pp}$.

FISHER, D. W. 1984. Bedrock geology of the Glens FallsWhitehall region, New York. New York State Museum Map and Chart Series 35, 58 pp.

FLOWER, R. H. 1941. Notes on the structure and phylogeny of eurysiphonate cephalopods. Palaeontographica Americana 3(13), 5-51.

Flower, R. H. 1952. Cephalopods from the Harding and Manitou Formations of Colorado. Journal of Paleontology 26, 505-27.

FLOWER, R. H. 1955. Status of endoceroid classification. Journal of Paleontology 29, 329-71.

FLOwER, R. H. 1956. Cephalopods from the Canadian of Maryland. Journal of Paleontology 3, 75-96. 
FLOWER, R. H. 1964a. The nautiloid order Ellesmeroceratida (Cephalopoda). New Mexico Institute of Mining and Technology, State Bureau of Mines and Mineral Resources, Memoir 12, 164 pp.

Flower, R. H. 1964b. Early Paleozoic in New Mexico. In Southwestern New Mexico, Guidebook 16th field conference (eds J. P. Fitzsimmons \& C. L. Balk), pp. 112-13. Socorro: New Mexico Geological Society.

FLOWER, R. H. 1964c. Nautiloid shell morphology. New Mexico Institute of Mining and Technology, State Bureau of Mines and Mineral Resources, Memoir 13, 1-77.

FLOWER, R. H. 1968. Fossils from the Fort Ann Formation. New Mexico Institute of Mining and Technology, State Bureau of Mines and Mineral Resources, Memoir 22, 29-34.

Flower, R. H. 1969. Early Paleozoic of New Mexico and El Paso region. In The Ordovician symposium (ed. D. V. LeMone), pp. 31-103. El Paso Geological Society and Permian Basin Society of Economic Paleontologists and Mineralogists.

FlOWER, R. H. 1976. Ordovician cephalopod faunas and their role in correlation. In The Ordovician System: Proceedings of a Palaeontological Association Symposium, Birmingham (England), September 1974 (ed. M. G. Bassett), pp. 523-52. Cardiff: University of Wales \& National Museum of Wales.

Flower, R. H. \& KUMMEL, B. 1950. A classification of the Nautiloidea. Journal of Paleontology 24, 604-16.

Foerste, A. F. 1921. Notes on Arctic Ordovician and Silurian Cephalopods, chiefly from Boothia FelixKing William Land, Bache Peninsula, and Bear Island. Denison University Bulletin, Journal of the Scientific Laboratories 19, 247-306.

Foerste, A. F. 1924. Notes on American Paleozoic cephalopods. Denison University Bulletin, Journal of the Scientific Laboratories 20, 193-268.

FOERSTE, A. F. 1925. Notes on cephalopod genera, chiefly coiled Silurian forms. Denison University Bulletin, Journal of the Scientific Laboratories 21, 1-69.

Foerste, A. F. 1936. Silurian cephalopods of the Port Daniel area on Gaspe Peninsula, Eastern Canada. Denison University Bulletin, Journal of the Scientific Laboratories 31, 21-92.

Frey, R. C., Beresi, M. S., Evans, D. H., King, A. H. \& Percival, I. G. 2004. Nautiloid cephalopods. In The Great Ordovician Biodiversification Event (eds B. D. Webby, F. Paris, M. L. Droser \& I. G. Percival), pp. 209-13. New York: Columbia University Press.

Furnish, W. M. \& GLENISTER, B. F. 1964a. NautiloideaEllesmerocerida. In Treatise on Invertebrate Paleontology, Part K, Mollusca 3 (ed. R. C. Moore), pp. K129-59. Boulder, Colorado and Lawrence, Kansas: Geological Society of America and the University of Kansas Press.

FURNish, W. M. \& GLENISTER, B. F. 1964b. NautiloideaTarphycerida. In Treatise on Invertebrate Paleontology, Part K, Mollusca 3 (ed. R. C. Moore), pp. K343-68. Boulder, Colorado and Lawrence, Kansas: Geological Society of America and the University of Kansas Press.

HaLl, J. 1847. Natural History of New York, Palaeontology, Vol. 1, containing descriptions of the organic remains of the lower division of the New-York system (equivalent of the Lower Silurian rocks of Europe). Albany: Van Benthuysen, $338 \mathrm{pp}$.

HintZe, L. F. 1953. Lower Ordovician trilobites from Western Utah and eastern Nevada. Utah Geological and Mineralogical Survey, Bulletin 48, 1-249.
HYATT, A. 1894. Phylogeny of an acquired characteristic. Proceedings of the American Philosophical Society 32, 349-647.

HYATT, A. 1900. Cephalopoda. In Textbook of Paleontology, 1 (ed. K. A. von Zittel; 2nd edn, trans./ed. C. R. Eastmann), pp. 502-92. London: Macmillan and Co., 839 pp.

KNOPF, E. B. 1927. Some results of recent work in the southern Taconic area. American Journal of Science 214, 429-58.

KNOPF, E. B. 1962. Stratigraphy and structure of the Stissing Mountain area, Dutchess County, New York. Stanford University Publications, Geological Sciences 7, 1-55.

KoBAYASHI, T. 1934. The Cambro-Ordovician formations and faunas of South Chosen. Palaeontology. Part II. Lower Ordovician faunas. Journal of the Faculty of Sciences of the Imperial University of Tokyo, Section II, Geology, Mineralogy, Geography, Seismology 3, 249328.

KobaYASHI, T. 1937. Contribution to the study of the apical end of Ordovician nautiloids. Japanese Journal of Geology and Geography 14, 1-21.

KRÖGER, B. 2003. The size of siphuncle in cephalopod evolution. Senckenbergiana lethaea 83, 39-52.

KRÖGER, B. 2004. Large shell injuries in Middle Ordovician Orthocerida (Nautiloidea, Cephalopoda). GFF 126, 311-16.

KRÖGER, B. 2005. Adaptive evolution in Paleozoic coiled Cephalopods. Paleobiology 31, 253-68.

KRÖGER, B. \& LANDING, E. 2007. The earliest Ordovician cephalopods of eastern Laurentia - Ellesmerocerids of the Tribes Hill Formation, Eastern New York. Journal of Paleontology 81, 841-57.

KRÖGER, B. \& MAPES, R. 2007. On the origin of bactritoids (Cephalopoda). Paläontologische Zeitschrift 81(3), 316-27.

KRÖGER, B. \& MUTVEI, H. 2005. Nautiloids with multiple paired muscle scars from Lower-Middle Ordovician of Baltoscandia. Palaeontology 48, 781-91.

LANDING, E. 1988. Depositional tectonics and biostratigraphy of the western portion of the Taconic allochthon, eastern New York State. In The Canadian Paleontology and Biostratigraphy Seminar, Proceedings (ed. E. Landing), pp. 96-110. New York State Museum Bulletin 462, $157 \mathrm{pp}$.

LANDING, E. 2002. Early Paleozoic sea levels and climates: new evidence from the east Laurentian shelf and slope. In Guidebook for Fieldtrips in New York and Vermont (eds J. McLelland \& P. Karabinos), pp. C6-1-22. New England Intercollegiate Geological Conference 94th Annual Meeting and New York State Geological Association 74th Annual Meeting, Lake George, New York.

Landing, E., Franzi, D. A., Hagadorn, J. W., Westrop, S. R., KRÖGER, B. \& DAWSON, J. 2007. Cambrian of East Laurentia: field workshop in eastern New York and western Vermont. In Ediacaran-Ordovician of East Laurentia (ed. E. Landing), pp. 16-34. New York State Museum Bulletin 510, 93 pp.

LANDING, E. \& WeStroP, S. R. 2006. Lower Ordovician faunas, stratigraphy, and sea-level history of the middle Beekmantown Group, northeastern New York. Journal of Paleontology 80, 958-80.

LANDING, E., WeSTROP, S. R. \& KNOX, L. 1996. Conodonts, stratigraphy, and relative sea-level changes of the Tribes Hill Formation (Lower Ordovician), east-central New York. Journal of Paleontology 70, 652-76. 
Landing, E., Westrop, S. R. \& Van Aller Hernick, L. 2003. Uppermost Cambrian-Lower Ordovician faunas and Laurentian platform sequence stratigraphy, eastern New York and Vermont. Journal of Paleontology 77, 78-98.

LANDING, E., WeStrop, S. R. \& KePPIE, J. D. 2007. Terminal Cambrian and lowest Ordovician succession of Mexican West Gondwana - biotas and sequence stratigraphy of the Tiñu Formation. Geological Magazine 144, 909-36.

MAgurRAn, A. E. 2004. Measuring biological diversity. Oxford: Blackwell Science, 260 pp.

MANDA, S. 2001. Some new or little known cephalopods from the Lower Devonian Pragian carbonate shelf (Prague Basin, Bohemia) with remarks on Lochkovian and Pragian cephalopod evolution. Journal of the Czech Geological Society 46, 269-86.

MURCHISON, R. I. 1859. On the succession of the older Rocks in the northernmost counties of Scotland; with some observations on the Orkney and Shetland Islands. The Quarterly Journal of the Geological Society of London 15, 353-418.

Repetski, J. E. 1982. Conodonts from the El Paso Group (Lower Ordovician) of westernmost Texas and southern New Mexico. New Mexico Bureau of Mines \& Mineral Resources, Memoir 40, 1-59.

Repetski, J. E., Loch, J. D. \& Ethington, R. E. 1998. Conodonts and biostratigraphy of the Lower Ordovician Roubidoux Formation in and near the Ozark National Scenic Riverways, southeastern Missouri. National Park Service, Technical Report D-1308, 109-15.

Rodgers, J. \& Fisher, D. W. 1969. Paleozoic rocks in Washington County, New York, west of the Taconic klippe. In Guidebook for Fieldtrips in New York, Massachusetts, and Vermont (ed. J. M. Bird), pp. 6.1-6.12. New England Intercollegiate Geological Conference, 61st Annual Meeting. State University of New York at Albany.

Ross, R. J. JR, Hintze, L. F., Ethington, R. L., Miller, J. F., TAylor, M. E., Repetski, J. E., Sprinkle, J. \& GUENSBURG, T. E. 1997. Observed ranges of trilobites, conodonts, echinoderms, molluscs, and brachiopods in the Ibexian Series composite stratotype section and adjacent rocks, House-Confusion Range area westcentral Utah. U.S. Geological Survey Professional Paper 1579-A, 1-50.

RuEDEMANN, R. 1905. The structure of some primitive cephalopods. New York State Museum Bulletin, 80(10), 269-341.
SCHRÖDER, H. 1891. Untersuchungen über silurische Cephalopoden. Paläontologische Abhandlungen, Neue Folge 1(4), 1-48.

SWOFFORD, D. L. 1993. PAUP: Phylogenetic Analysis Using Parsimony, Version 3.1.1. Illinois Natural History Survey, $257 \mathrm{pp}$.

TEICHERT, C. 1933. Der Bau der actinoceroiden Cephalopoden. Palaeontographica, A 77, 111-230.

TEICHERT, C. 1964. Endoceratoidea. In Treatise on Invertebrate Paleontology, Part K, Mollusca 3 (ed. R. C. Moore), pp. K160-89. Boulder, Colorado, and Lawrence, Kansas: Geological Society of America and the University of Kansas Press.

Ulrich, E. O. \& Foerste, A. F. 1935. New Genera of Ozarkian and Canadian cephalopods. Journal of the Scientific Laboratories of Denison University 30, 25990.

Ulrich, E. O., Foerste, A. F., Miller, A. K. \& Furnish, W. M. 1942. Ozarkian and Canadian cephalopods. Part I: Nautilicones. Geological Society of America Special Papers 37, $157 \mathrm{pp}$.

Ulrich, E. O., Foerste, A. F. \& Miller, A. 1943. Ozarkian and Canadian cephalopods. Part II: Brevicones. Geological Society of America Special Papers 59, 240 pp.

Ulrich, E. O., Foerste, A. F., Miller, A. \& UnKLesbay, A. G. 1944. Ozarkian and Canadian cephalopods Part III: Longicones and summary. Geological Society of America Special Papers 58, 226 pp.

UnKLESBAY, A. G. 1961. Nautiloids from the Gorman and Honeycut of Central Texas. Journal of Paleontology 35, 373-9.

Unklesbay, A. G. \& Young, R. S. 1956. Early Ordovician nautiloids from Virginia. Journal of Paleontology 30, 481-91.

VANUXEM, L. 1842. Geology of New York, Pt. 3, Comprising the survey of the Third Geological District. Albany: W. \& A. White \& J. Visscher, 306 pp.

WHITFIELD, R. P. 1886. Notice of geological investigations along the eastern shore of Lake Champlain, conducted by Prof. H. M. Seeley and Prest. Ezra Brainerd, of Middlebury College, with descriptions of the new fossils discovered. American Museum of Natural History Bulletin 1, 293-345.

Whitfield, R. P. 1889. Descriptions of new species of Silurian fossils from the Calciferous sandrock of Lake Champlain and description of several new forms. American Museum of Natural History Bulletin 2, 41-63. 